\title{
Understanding runoff processes in a semi-arid environment through isotope and hydrochemical hydrograph separations
}

\author{
V. V. Camacho Suarez ${ }^{1}$, A. M. L. Saraiva Okello ${ }^{1,2}$, J. W. Wenninger ${ }^{1,2}$, and S. Uhlenbrook ${ }^{1,2}$ \\ ${ }^{1}$ Department of Water Science and Engineering, UNESCO-IHE Institute for Water Education, P.O. Box 3015, \\ 2601 DA Delft, the Netherlands \\ ${ }^{2}$ Section of Water Resources, Delft University of Technology, P.O. Box 5048, 2600 GA Delft, the Netherlands \\ Correspondence to: V. V. Camacho Suarez (viviancamacho@gmail.com)
}

Received: 19 December 2014 - Published in Hydrol. Earth Syst. Sci. Discuss.: 22 January 2015

Revised: 2 October 2015 - Accepted: 5 October 2015 - Published: 20 October 2015

\begin{abstract}
The understanding of runoff generation mechanisms is crucial for the sustainable management of river basins such as the allocation of water resources or the prediction of floods and droughts. However, identifying the mechanisms of runoff generation has been a challenging task, even more so in arid and semi-arid areas where high rainfall and streamflow variability, high evaporation rates, and deep groundwater reservoirs may increase the complexity of hydrological process dynamics. Isotope and hydrochemical tracers have proven to be useful in identifying runoff components and their characteristics. Moreover, although widely used in humid temperate regions, isotope hydrograph separations have not been studied in detail in arid and semiarid areas. Thus the purpose of this study is to determine whether isotope hydrograph separations are suitable for the quantification and characterization of runoff components in a semi-arid catchment considering the hydrological complexities of these regions. Through a hydrochemical characterization of the surface water and groundwater sources of the catchment and two- and three-component hydrograph separations, runoff components of the Kaap catchment in South Africa were quantified using both isotope and hydrochemical tracers. No major disadvantages while using isotope tracers over hydrochemical tracers were found. Hydrograph separation results showed that runoff in the Kaap catchment is mainly generated by groundwater sources. Two-component hydrograph separations revealed groundwater contributions of between 64 and $98 \%$ of total runoff. By means of threecomponent hydrograph separations, runoff components were further separated into direct runoff, shallow and deep groundwater components. Direct runoff, defined as the direct precip-
\end{abstract}

itation on the stream channel and overland flow, contributed up to $41 \%$ of total runoff during wet catchment conditions. Shallow groundwater defined as the soil water and nearsurface water component (and potentially surface runoff) contributed up to $45 \%$ of total runoff, and deep groundwater contributed up to $84 \%$ of total runoff. A strong correlation for the four studied events was found between the antecedent precipitation conditions and direct runoff. These findings suggest that direct runoff is enhanced by wetter conditions in the catchment that trigger saturation excess overland flow as observed in the hydrograph separations.

\section{Introduction}

Understanding runoff processes facilitates the evaluation of surface water and groundwater risks with respect to quality and quantity (Uhlenbrook et al., 2002). It assists in quantifying water resources for water allocation, hydropower production, design of hydraulic structures, environmental flows, drought and flood management, and water quality purposes (Blöschl et al., 2013). The need for understanding runoff processes has led to the development of tools such as hydrograph separation techniques that identify runoff components in streamwater, flowpaths, residence times and contributions to total runoff (Klaus and McDonnell, 2013; Hrachowitz et al., 2009; Weiler et al., 2003). Several hydrograph separation studies using environmental isotopes and geochemical tracers have been carried out in forested, semi-humid environments, which have led to new insights into runoff processes in these areas (e.g., Pearce et al., 1986; Bazemore et al., 1994; 


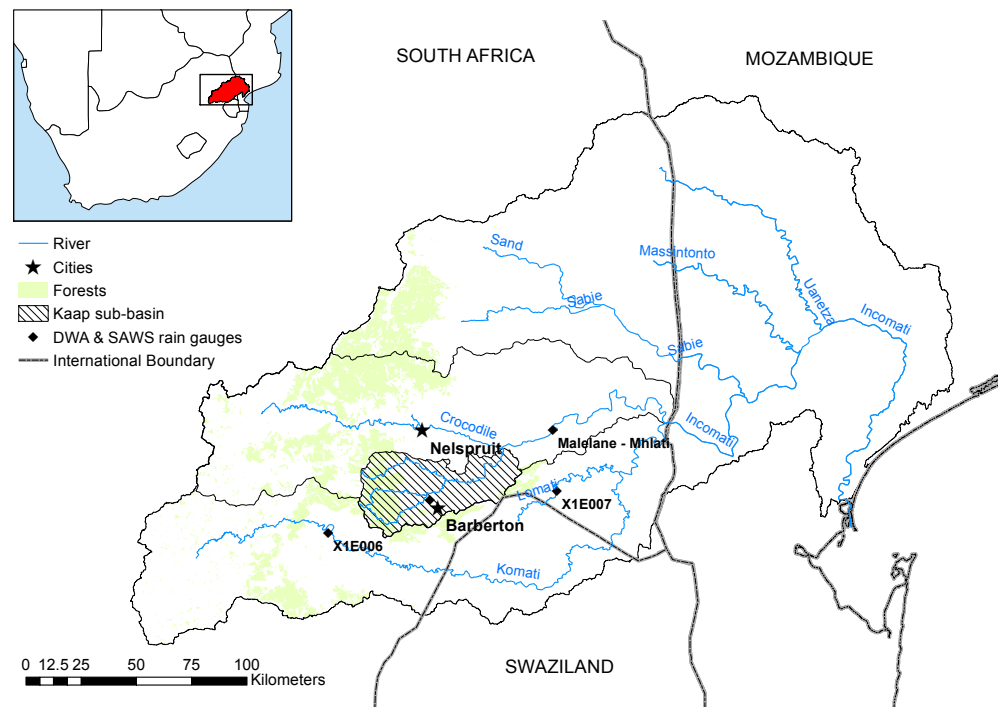

Figure 1. Location of the Kaap catchment in the Incomati Basin displaying nearby cities, and DWA and SAWS rain gauges.

Tetzlaff and Soulsby, 2008; Uhlenbrook et al., 2002; Burns et al., 2001). But there is still a need for understanding runoff generation mechanisms in tropical, arid and semi-arid areas, as they were much less investigated (Burns, 2002).

Studying runoff processes in arid and semi-arid regions may be a challenging task due to the high temporal and spatial variability of rainfall, high evaporation rates, deep groundwater resources, poorly developed soils, and in some cases the lack of surface runoff (Blöschl et al., 2013; Hrachowitz et al., 2011; Wheater et al., 2008). Although these challenges may not be applicable in various instances (e.g., a reduced vegetation cover results in less importance of the interception process), arid and semi-arid regions may still face extra difficulties due to their remoteness and financial constraints.

Arid and semi-arid regions are characterized by their sporadic, high-energy, and low-frequency precipitation occurrence (Camarasa-Belmonte and Soriano, 2014; Wheater et al., 2008). Dry spells can last for years, and rain events may vary from a few millimeters to hundreds of millimeters per year. High-intensity storms may generate most if not all the season's runoff (Love et al., 2010; Van Wyk et al., 2012). These events can also increase erosion, reduce soil infiltration capacity and enhance surface runoff (CamarasaBelmonte and Soriano, 2014). On the contrary, the lack of precipitation may result in reduced to non-existent groundwater recharge. Compared to humid regions, where evaporation is generally limited by the amount of energy available, evaporation in arid and semi-arid areas is usually limited by the water availability in the catchment (Wang et al., 2013). Evaporation becomes the dominant factor in driving the hydrology of arid and semi-arid areas. Understanding the impact of evaporation on stream runoff processes becomes more complex due to the spatial variability of vegetation. An increase in vegetation cover due to a wetter rainfall season may result in higher evaporation rates, reduced streamflow and increased soil infiltration capacity (Hughes et al., 2007; Mostert et al., 1993). Transmission losses through the stream channel bed may also reduce the total runoff and increase the volume of recharged groundwater. This occurrence is evident in the entire Incomati Basin, where downstream areas (e.g., Mozambique) benefit from transmission losses and return flows of upstream areas (Nkomo and van der Zaag, 2004; Sengo et al., 2005).

This paper explores the runoff processes, including surface-groundwater interactions in the Kaap catchment, South Africa, by describing the spatial hydrochemical characterization of the catchment, separating the runoff components through isotope and geochemical tracer analysis, and determining the suitability of isotopic tracers for the characterization of runoff components in the catchment.

\section{Study area}

The Kaap catchment is located in the northeast of South Africa in the Mpumalanga province and has an area of approximately $1640 \mathrm{~km}^{2}$ (Fig. 1). Nelspruit, the provincial capital, and Barberton are the closest urban areas to the Kaap, with populations of approximately 125000 and 35000 inhabitants, respectively (GRIP, 2012). The study area is predominantly located in the low-elevation sub-tropical region of South Africa, Swaziland and Mozambique known as the Lowveld region, with elevations ranging from 300 to $1800 \mathrm{~m}$ a.s.l. (above sea level). The average slope is $18 \%$.

The geology dates back to Archean times. Biotite granite is the predominant formation in the valley (Fig. 2c). Headwater streams originate on the weathered granite, whose fel- 
sic properties indicate high concentrations of dissolved silica. Surrounding granite, lava formations or Onverwacht formations contain basaltic and peridotitic komatiite, which are low in silicates and high in magnesium. The Onverwacht formation is one of the oldest formations in the area. Formed in an ocean, it is rich in quartz, volcanic rocks and chert horizons (de Wit et al., 2011). Sandstones and shales are found in closer proximity to the Kaap River and at the southern section of the catchment. In addition to the gneiss formation observed near the outlet, other formations include ultramafic (high in iron and low in silicates) rocks, quartzite and dolomite (Sharpe et al., 1986). Borehole logs near the upper Suidkaap and Noordkaap tributaries displayed a top layer of weathered granite (approximately 25 to $37 \mathrm{~m}$ in depth) followed by a thinner, less fractured granite layer and hard rock granite. Borehole logs analyzed in closer proximity to the catchment outlet presented more diverse formations including layers of clay, sand, greywacke and weathered shale.

Bushveld and grasslands are the predominant land cover types in the Kaap Valley, covering up to $68 \%$ of the catchment (Fig. 2b). In the upstream region (western part of the catchment), approximately $25 \%$ of the total catchment consists of pine and eucalyptus plantations used for paper and timber production. Sugar cane, citrus trees, and other cash crops are found in the downstream region where many diversion channels for irrigation are present. Irrigation demand in the Kaap catchment is approximately $56 \mathrm{~mm} \mathrm{a}^{-1}$ (Mallory and Beater, 2009).

The climate is semi-arid with cool dry winters and hot wet summers. Precipitation ranges from 583 to $1243 \mathrm{~mm} \mathrm{a}^{-1}$ (WRC, 2005) with an average annual precipitation of $742 \mathrm{~mm} \mathrm{a}^{-1}$, and a mean annual runoff coefficient of 0.14 . Between 2001 and 2012, recorded minimum and maximum daily air temperatures at the Barberton meteorological station ranged from 3 to $42^{\circ} \mathrm{C}$, with a long-term average of $20^{\circ} \mathrm{C}$ (SASRI, 2013). The wet season lasts typically from October to March, as shown in Fig. 3, where the climate diagram shows the monthly averages (from 2001 to 2012) of precipitation, pan A evaporation from four weather stations (X1E006, X1E007, Barberton, and Malelane) and maximum and minimum temperatures at the Barberton station. A dry season is observed from May to September. Class-A-pan evaporation rates largely exceed precipitation during most parts of the year. The range of long-term potential evapotranspiration (PET) shown in Fig. 2f for the catchment (19502000) is between 1500 and $1900 \mathrm{~mm} \mathrm{a}^{-1}$ (Schulze, 1997). The PET data show that most of the catchment is semiarid, according to the UNEP definition (UNEP, 1997), as illustrated in Fig. 2e (aridity index $=$ mean annual precipitation/mean annual potential evaporation). However, according to the Köppen-Geiger classification, the catchment is subtropical.

The Kaap catchment contains three main tributaries: the Queens, the upper Suidkaap, and the Noordkaap. The highest monthly average flow during the year occurs in February, with an average of $9.2 \mathrm{~m}^{3} \mathrm{~s}^{-1}$. The lowest monthly flow during the year occurs at the end of the dry season in September, reaching an average of $0.8 \mathrm{~m}^{3} \mathrm{~s}^{-1}$. Minimum and maximum daily average flows recorded between 1961 and 2012 at the Kaap outlet range from 0 to $483 \mathrm{~m}^{3} \mathrm{~s}^{-1}$. The long-term mean flow at the outlet is $3.7 \mathrm{~m}^{3} \mathrm{~s}^{-1}$, which is equivalent to $55 \mathrm{~mm} \mathrm{a}^{-1}$.

Although analytical methods for hydrograph separation have been carried out in the Kaap River, no accurate estimations of runoff components were retrieved in the area. Thus, this paper also provides a baseline for understanding surface and groundwater dynamics in the Incomati trans-boundary river system. The Kaap River is a major contributor of flow to the Crocodile River, which flows into the Incomati transboundary river. The Incomati waters are shared by South Africa, Swaziland and Mozambique, where tensions related to the management of water resources have led to the development of water-sharing agreements such as the Tripartite Interim Agreement on Water Sharing of the Maputo and Incomati Rivers (Van der Zaag and Carmo Vaz, 2003). The need for reliable data and understanding of the hydrological functioning of the system has been highlighted in these agreements (Slinger et al., 2010). In addition, the Kaap River and the neighboring catchments experienced devastating floods in February 2000 and March 2014 with return periods exceeding 200 years (Smithers et al., 2001).

\section{Data and methods}

\subsection{Long-term data sets}

Hydrological data in the catchment, including precipitation, evaporation, streamflow and groundwater records, were collected from the Department of Water Affairs (DWA), the South African Weather Service (SAWS), the South African Sugarcane Research Institute (SASRI), and the In-Situ Groundwater Consulting firm (http://www.insituconsulting. co.za). Geological, topographical and land use GIS (geographic information systems) data were obtained from the 2005 Water Research Commission study (WRC, 2005).

The average catchment precipitation was obtained by studying seven weather stations with daily rainfall data from 2001 to 2012. Only four stations were selected based on data availability and proximity to the catchment. These stations were X1E006, X1E007, Barberton and Malelane (Fig. 1). Missing rainfall values for Barberton (2\%) and X1E007 $(33 \%)$ were estimated by regression analysis. Malelane and X1E006 did not contain missing data. Using a Thiessen polygon distribution, the average rainfall was calculated for the catchment.

Average actual evaporation was calculated from daily Class-A-pan evaporation values from the Barberton and Malelane stations and daily Class-S-pan evaporation from X1E006 and X1E007 stations from 2003 to 2012. Daily pan 


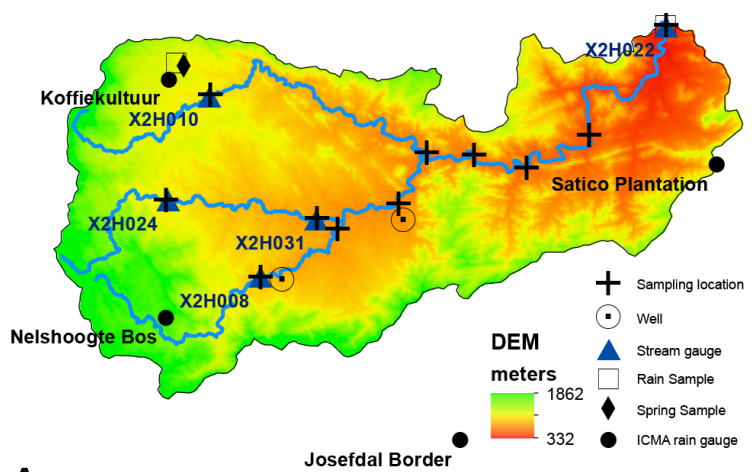

A
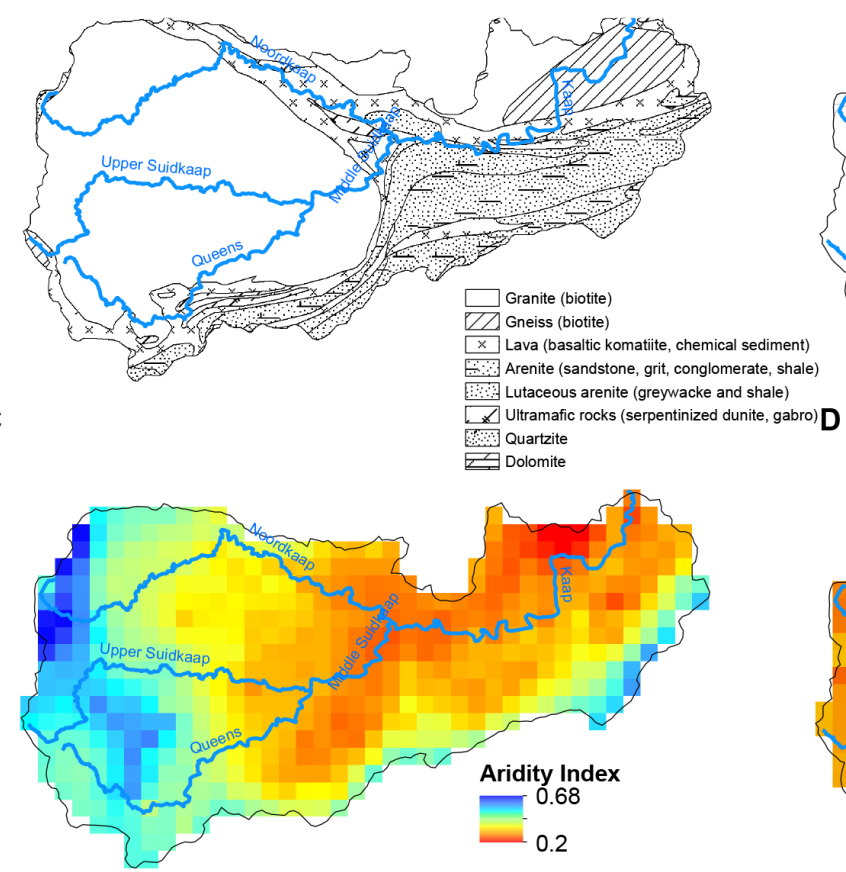

E

Figure 2. (a) Digital elevation model (DEM) of the Kaap catchment with sampling locations and stream and rain gauge locations, (b) land use map, (c) geological map, (d) contour map of static groundwater levels, (e) aridity index ( $<0.03$ hyper arid, 0.03-0.2 arid, 0.2-0.5 semi-arid, 0.5-0.65 dry sub-humid, $>0.65$ humid) and (f) long-term mean potential evapotranspiration (PET). GIS layers are courtesy of the Water Research Commission (2005), South Africa.

evaporation values were aggregated to monthly pan evaporation values. Class-S-pan evaporation was converted to ClassA-pan evaporation following the WR90 Water Resources of South Africa study (Midgley et al., 1994). Class-A evaporation was converted to reference evaporation using the guidelines for crop water requirements (Allen et al., 1998) and reference evaporation was corrected for the specific land uses using data from the land satellite imagery collected from the Incomati Water Availability Assessment Study (Mallory and Beater, 2009). Using a long-term water balance from 2003 to 2012, actual mean evaporation rates were found.

To analyze the streamflow response at the outlet and tributaries, daily discharges at the $\mathrm{X} 2 \mathrm{H} 022$ (outlet), $\mathrm{X} 2 \mathrm{H} 008$
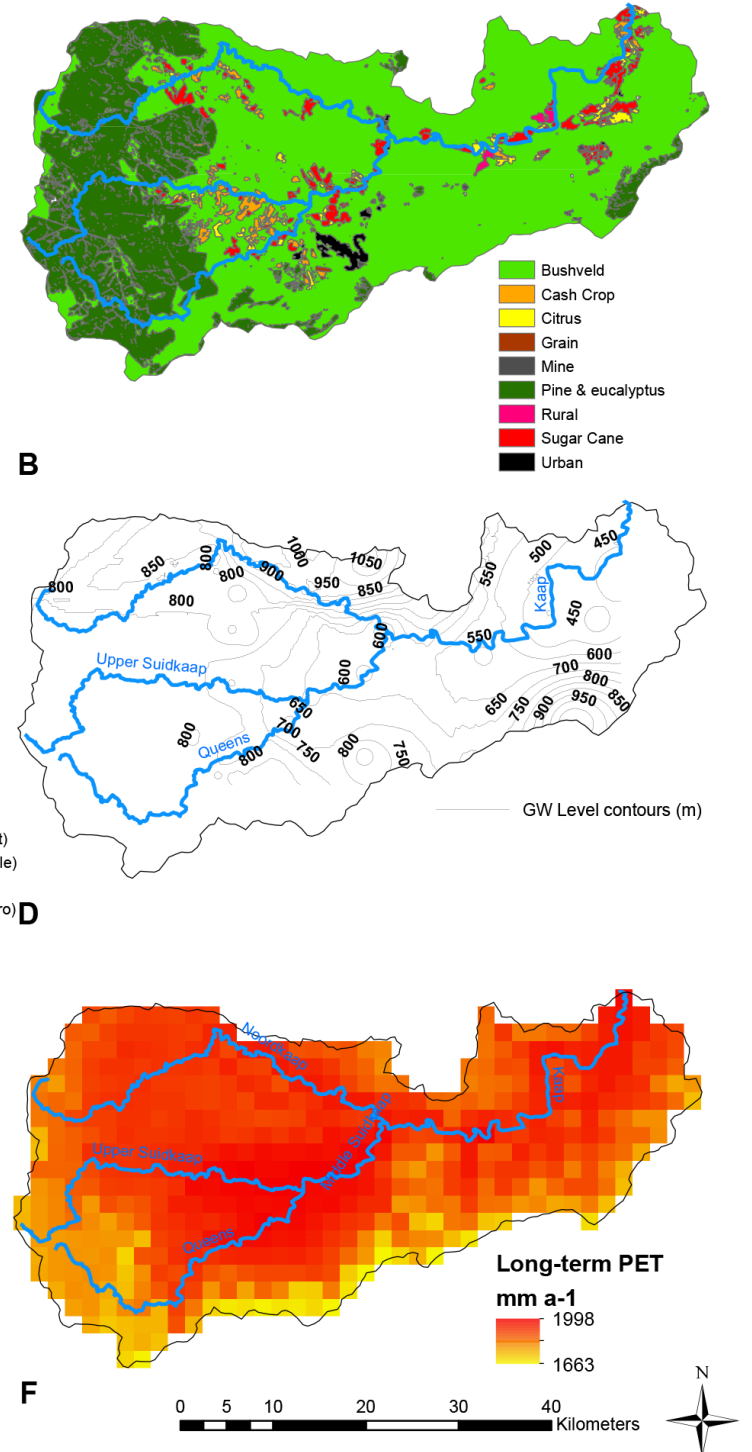

(Queens), X2H031 and X2H024 (Suidkaap) and X2H010 (Noordkaap) stream gauges were obtained from the DWA. The locations of the stations are shown in Fig. 2a.

\subsection{Field and laboratory methods}

\subsubsection{General}

A field campaign from 20 November 2013 to 4 February 2014 was carried out to obtain an overview of the hydrochemistry of the catchment prior to the rainy season and to collect data for hydrograph separation studies. 
Table 1. UNESCO-IHE laboratory equipment used in chemical analysis of Kaap catchment samples.

\begin{tabular}{|c|c|c|c|c|c|}
\hline & $\begin{array}{l}\text { Parameter(s) } \\
\text { analyzed }\end{array}$ & Equipment & $\begin{array}{l}\text { Number } \\
\text { of } \\
\text { samples }\end{array}$ & $\begin{array}{l}\text { Preservation } \\
\text { method }\end{array}$ & $\begin{array}{l}\text { Analytical } \\
\text { uncertainty } \\
(\sigma)\end{array}$ \\
\hline $\begin{array}{l}\text { Environmental } \\
\text { isotopes }\end{array}$ & ${ }^{18} \mathrm{O},{ }^{2} \mathrm{H}$ & $\begin{array}{l}\text { LRG DLT-100 } \\
\text { isotope analyzer }\end{array}$ & 116 & None & $\pm 0.2, \pm 1.5(\% \circ)$ \\
\hline Cations & $\mathrm{Ca}^{2+}, \mathrm{Mg}^{2+}, \mathrm{Na}^{+}, \mathrm{K}^{+}$ & $\begin{array}{l}\text { Thermo Fisher } \\
\text { Scientific XSeries } 2 \\
\text { ICP-MS }\end{array}$ & 116 & $\begin{array}{l}\text { Nitric acid } \\
\left(\mathrm{HNO}_{3}\right)\end{array}$ & $\pm 0.2\left(\mathrm{mg} \mathrm{L}^{-1}\right)$ \\
\hline Anions & $\begin{array}{l}\mathrm{Cl}^{-}, \mathrm{NO}_{3}^{-}-\mathrm{N}, \mathrm{SO}_{4}^{2-} \\
\mathrm{PO}_{4}^{3-}\end{array}$ & Dionex ICS-1000 & 116 & $\begin{array}{l}\text { Refrigerated at } \\
<4^{\circ} \mathrm{C}\end{array}$ & $\pm 0.2\left(\mathrm{mg} \mathrm{L}^{-1}\right)$ \\
\hline
\end{tabular}

Stream discharge collected from DWA data loggers (water levels converted to stream discharge using the DWA rating curve) were retrieved at the outlet with a frequency of 12 min $(0.2$ h) from 30 October 2013 to 17 February 2014. Hourly precipitation rates were obtained from the Incomati Catchment Management Agency (ICMA) rain gauges at Koffiekultuur, Nelshoogte Bos, Satico, and the Josefdal border from 1 October 2013 to 28 February 2014 (see locations in Fig. 2a).

\subsubsection{Water samples}

Water samples were collected from the tributaries, the main river, one spring, and two drinking water wells as shown in Fig. 2a. Each location was sampled twice during dry weather conditions. Each sample of approximately $250 \mathrm{~mL}$ was collected in polyethylene bottles, rinsed three times before the final sample was taken to avoid contamination, and refrigerated for sample preservation. Electrical conductivity (EC), $\mathrm{pH}$ and temperature were measured in situ using a Wissenschaftlich-Technische-Werkstätten (WTW) conductivity meter.

\subsubsection{Rain sampling}

To obtain the isotopic and hydrochemical reference of rainfall, bulk rain samples were collected in the upstream and downstream parts of the catchment. The rain samplers were constructed according to standards of the International Atomic Energy Agency (IAEA) to avoid re-evaporation (Gröning et al., 2012). Thus, an average of upstream and downstream samples per rain event was used for the rainfall end-member concentrations for each hydrograph separation.

Rainfall characteristics, including duration, total rain amount, and maximum and average intensity, and the Antecedent Precipitation Index (API) were estimated for each rain event. A rainfall event was defined as a rainfall occurrence with rainfall intensity greater than $1 \mathrm{~mm} \mathrm{~h}^{-1}$ and intermittence less than $4 \mathrm{~h}$, as observed in a similar study in a semi-arid area by Wenninger et al. (2008). The API for $n$ days prior to the event was calculated using Eq. (1):

$\mathrm{API}_{-n}=\sum_{i=1}^{7} P_{(-n-1+i)}(0.1 i)$,

where $P$ in $\mathrm{mm} \mathrm{h}^{-1}$ stands for precipitation and $i$ is the number corresponding to the day of rainfall. For this study, APIs were calculated for the 7,14 , and 30 days prior to the event. Peak flow, runoff depth, and time to peak were determined for each event.

\subsubsection{Automatic sampler}

During the 2013-2014 rainy season, four events that occurred on 12-13 December (Event 1), 28-30 December (Event 2), 13 January (Event 3), and 30-31 January (Event 4) were sampled using an automatic sampler manufactured by the University of KwaZulu-Natal (UKZN). The first two events were sampled on a volume basis obtaining 22 samples for Event 1 and 5 samples for Event 2 (a smaller number of samples were obtained for Event 2 due to photo sensor failure in the automatic sampler). Events 3 and 4 were sampled using a time-based strategy obtaining 13 samples for Event 3, and 36 samples for Event 4 . A total volume of approximately $100 \mathrm{~mL}$ was obtained for each sample.

\subsubsection{Chemical analysis of water samples}

All samples were refrigerated, filtered, and analyzed for $\mathrm{HCO}_{3}$ and $\mathrm{Cl}$ using a Hach Digital Titrator, and $\mathrm{SiO}_{2}$ using a Hach DR890 Portable Colorimeter, within $48 \mathrm{~h}$. Then, samples were transported to the UNESCO-IHE laboratory in the Netherlands for further chemical analysis. The samples were analyzed for major anions, cations, and stable isotopes as listed in Table 1. 


\subsection{Data analysis}

\subsubsection{Groundwater analysis}

Groundwater chemical data for 240 boreholes and 18 borehole logs were obtained from In-Situ Groundwater Consultants covering the different geological formations (granite, lava, arenite, and gneiss). For 27 out of the 240 boreholes, $\mathrm{pH}, \mathrm{CaCO}_{3}, \mathrm{Mg}, \mathrm{Ca}, \mathrm{Na}, \mathrm{K}, \mathrm{Cl}, \mathrm{NO}_{3}-\mathrm{N}, \mathrm{F}, \mathrm{SO}_{4}, \mathrm{SiO}_{2}, \mathrm{Al}$, $\mathrm{Fe}$, and $\mathrm{Mn}$ data were available. The remaining boreholes only had information on EC, static water table depth, and physical characteristics of the borehole.

Borehole chemical data were classified according to the geological formations. The classified data distribution was observed using GIS, and basic statistical analysis was carried out to determine the control of geology over the hydrochemistry of groundwater.

To gain better insights with regard to groundwater flow, groundwater contour lines were created using an inversed distance-weighted (IDW) interpolation of the static water tables from the boreholes.

\subsubsection{End-member mixing analysis (EMMA)}

Suitable parameters for hydrograph separation were identified by creating mixing diagrams of $\mathrm{EC}\left(\mu \mathrm{S} \mathrm{cm}^{-1}\right), \mathrm{SiO}_{2}$, $\mathrm{CaCO}_{3}, \mathrm{Cl}, \mathrm{SO}_{4}, \mathrm{Na}, \mathrm{Mg}, \mathrm{K}, \mathrm{Ca}$ (in $\mathrm{mg} \mathrm{L}^{-1}$ ) and $\delta^{2} \mathrm{H}$ and $\delta^{18} \mathrm{O}$ (\%o VSMOW). Parameters were plotted against discharge to observe dilution and hysteresis effects. A principal component analysis was carried out based on the method described by Christophersen and Hooper (1992). Only nonstatistically correlated parameters were used. From these, the possibility of three end-members was explored. The three runoff components identified were direct runoff, deep groundwater and shallow groundwater. Direct runoff was defined according to the conceptual model by Uhlenbrook and Leibundgut (2000) where direct runoff (or the quick runoff component) was generated from direct precipitation on the stream channel, and overland flow from sealed and saturated areas and from highly fractured outcrops. The deep groundwater component was considered to be the portion of runoff generated from deeper highly weathered granite aquifers, and the shallow groundwater component was considered to be the intermediate component from perched groundwater tables.

The mixing plot for $\delta^{2} \mathrm{H}$ and $\mathrm{K}$ is presented in Fig. 11 . The direct runoff end-member was characterized by the upstream and downstream rain samples. Potassium was used as an indicator of the shallow groundwater component due to the main sources of potassium, which are the weathering of minerals from silicate rocks, application of fertilizers, and the decomposing of organic material. The mobilization of potassium is linked to the flushing of the soil and shallow subsurface layers of vegetated areas. This was also observed by Winston and Criss (2002). The direct runoff samples had a low K average $\left(0.5 \mathrm{mg} \mathrm{L}^{-1}\right)$ and depleted $\delta^{18} \mathrm{O}$ and

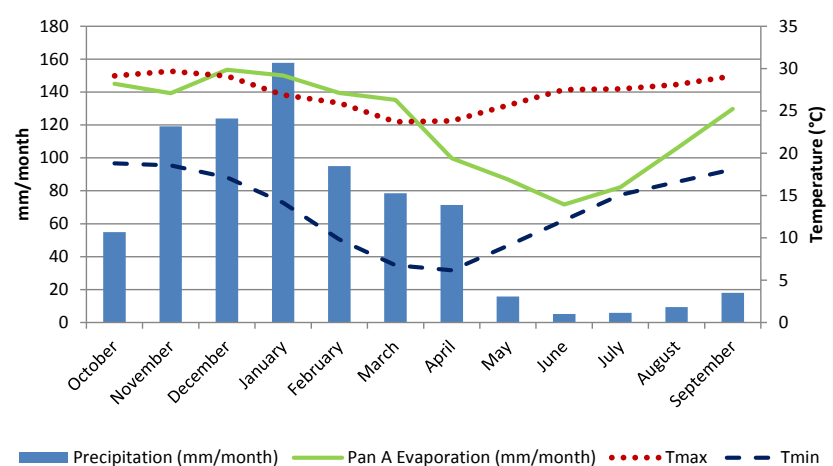

Figure 3. Average monthly precipitation, pan-A evaporation (from stations X1E006, X1E007, Barberton and Malelane), and maximum and minimum temperatures at Barberton station from 2001 to 2012.

$\delta^{2} \mathrm{H}$ values $\left(-4.8 \%\right.$ or $\delta^{18} \mathrm{O} ;-27.5 \%$ for $\left.\delta^{2} \mathrm{H}\right)$. A spring sample was used to characterize the deep groundwater component that contained more enriched $\delta^{18} \mathrm{O}$ and $\delta^{2} \mathrm{H}$ values $\left(-0.9 \%\right.$ of $\delta^{18} \mathrm{O} ;-2.2 \%$ of $\left.\delta^{2} \mathrm{H}\right)$ and low $\mathrm{K}$ concentration $\left(0.7 \mathrm{mg} \mathrm{L}^{-1}\right)$. The shallow groundwater end-member was estimated considering the high $\mathrm{K}$ concentrations $\left(4 \mathrm{mg} \mathrm{L}^{-1}\right)$ and slightly less depleted $\delta^{18} \mathrm{O}$ and $\delta^{2} \mathrm{H}\left(-3.5 \%\right.$ for $\delta^{18} \mathrm{O}$; $-7.0 \%$ for $\delta^{2} \mathrm{H}$ ) observed in the stream samples. The error interval for the direct runoff in Fig. 11 is \pm the standard deviation of the rain samples. For the groundwater end-members, the error intervals were estimated as $\pm 10 \%$ of the measured values. While these errors are arbitrary, they were chosen as they are more conservative than the alternative analytical errors of $\pm 0.2 \mathrm{mg} \mathrm{L}^{-1}$ for $\mathrm{K}$ and $\pm 1.5 \%$ ofor $\delta^{2} \mathrm{H}$ and because there were no additional samples from which to derive the standard deviation.

\subsubsection{Hydrograph separation}

Isotope and hydrochemical data were combined with discharge data to perform a multi-component hydrograph separation based on steady-state mass balance equations as described, for instance, in Uhlenbrook et al. (2002). The number of tracers $(n-1)$ was dependent on the number of runoff components $(n)$. Equations (3) and (4) were applied in dividing the total runoff, $Q_{\mathrm{T}}$, into two and three runoff components.

$Q_{\mathrm{T}}=Q_{1}+Q_{2} \ldots+Q_{n}$,

$c_{\mathrm{T}} Q_{\mathrm{T}}=c_{1} Q_{1}+c_{2} Q_{2} \ldots+c_{n} Q_{n}$,

where $Q_{1}, Q_{2}$ and $Q_{n}$ are the runoff components in $\mathrm{m}^{3} \mathrm{~s}^{-1}$ and $c_{\mathrm{T}}, c_{1}, c_{2}$ and $c_{n}$ are the concentrations of total runoff, and runoff components.

\subsubsection{Uncertainty estimation}

Uhlenbrook and Hoeg (2003) showed that during the quantification of runoff components, uncertainties due to tracer 


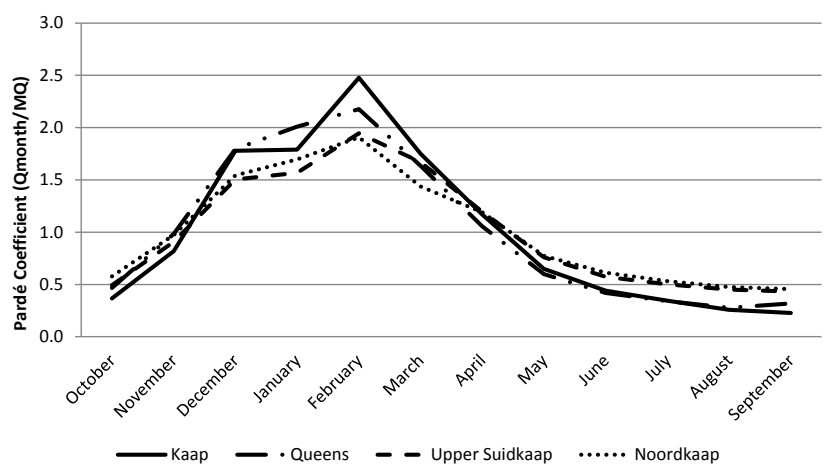

Figure 4. Annual flow regimes at $\mathrm{X} 2 \mathrm{H} 022$ (outlet), $\mathrm{X} 2 \mathrm{H} 008$ (Queens), X2H031 and X2H024 (Suidkaap) and X2H010 (Noordkaap) based on long-term flow data.

and analytical measurements, intra-storm variability, elevation and temperature, solution of minerals, and the spatial heterogeneity of the parameter concentrations occur. For the Kaap River hydrograph separations, these uncertainties were accounted for by the spatial hydrochemical characterization of the catchment and by sampling rainfall during each event and at different locations. Moreover, tracer end-members and analytical uncertainties were estimated using a Gaussian error propagation technique and a confidence interval of $70 \%$ as described by Genereux (1998) and Liu et al. (2004).

$W=\left\{\left[\frac{\partial y}{\partial x_{1}} W_{x 1}\right]^{2}+\left[\frac{\partial y}{\partial x_{2}} W_{x 2}\right]^{2}+\ldots+\left[\frac{\partial y}{\partial x_{n}} W_{x s}\right]^{2}\right\}^{\frac{1}{2}}$

$W$ is the estimated uncertainty of each runoff component (e.g., direct runoff, shallow and deep groundwater components). $W_{x 1}$ and $W_{x 2}$ are the standard deviations of the endmembers. $W_{x s}$ is the analytical uncertainty and the partial derivatives $\frac{\partial y}{\partial x_{1}}, \frac{\partial y}{\partial x_{2}}$ and $\frac{\partial y}{\partial x_{n}}$ are the uncertainties of the runoff component contributions with respect to the tracer concentrations.

\section{Results}

\subsection{Hydrology, hydrogeochemistry and groundwater flow}

One of the characteristics of semi-arid areas is the high variability of flows. This large variability is observed at the Kaap outlet and tributaries (Table 2), where the highest and lowest flows recorded at the Kaap outlet are 483 and $0 \mathrm{~m}^{3} \mathrm{~s}^{-1}$, respectively. Pardé coefficients (Fig. 4) reflect the seasonal flow behavior showing the dominance of one rainy season per hydrological year with the largest flows occurring in February. Moreover, the flat slopes observed at the upper end of the flow duration curves (Fig. 5) are evidence of groundwater storage areas located in the upstream part of the catchment.

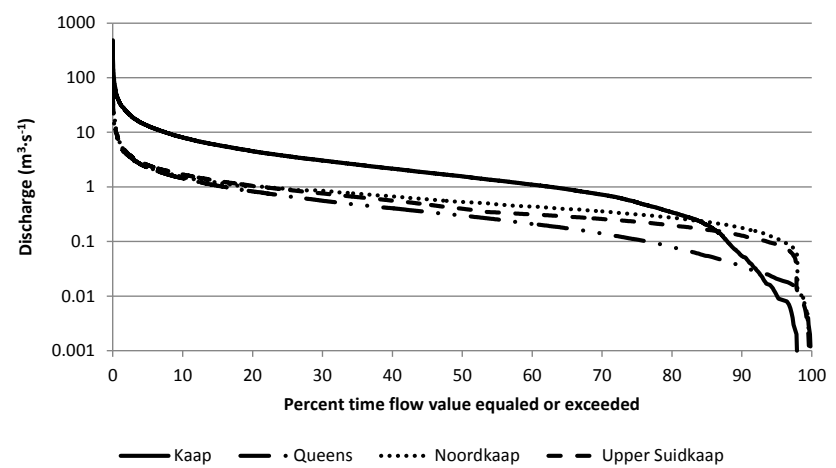

Figure 5. Flow duration curves for X2H022 (outlet), X2H008 (Queens), X2H031 and X2H024 (Suidkaap) and X2H010 (Noordkaap) based on long-term flow data.
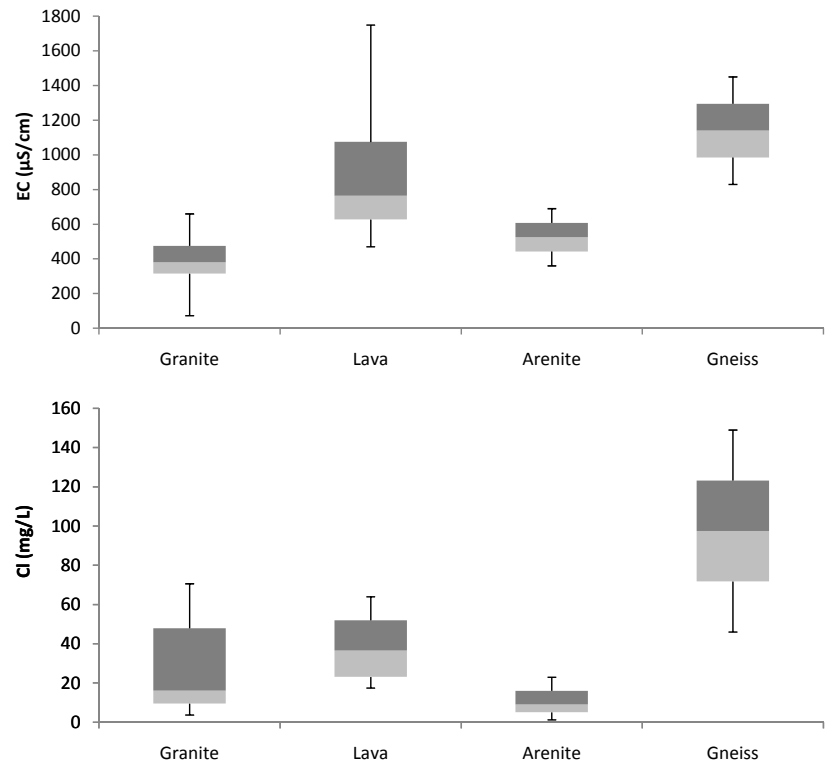

Figure 6. Boxplots of borehole water quality parameters at different geological locations in the Kaap catchment.

The variability of the catchment's groundwater quality parameters was studied from borehole data. Electrical conductivities in the granite region had the lowest electrical conductivity (EC) values (average $383 \mu \mathrm{S} \mathrm{cm}^{-1}$ ), while the gneiss formation, near the outlet, had the largest EC average of $1140 \mu \mathrm{S} \mathrm{cm}^{-1}$. Lava and arenite formations had mean EC values of 938 and $525 \mu \mathrm{S} \mathrm{cm}^{-1}$, respectively. The gneiss and lava formations had higher concentration averages of chloride and calcium carbonate than the granite and arenite formations. These can be seen in the boxplots in Fig. 6 .

Groundwater contour lines followed the topographical relief. The highest water tables were observed at the northern boundary of the catchment, with water tables up to $1150 \mathrm{~m}$ (Fig. 2d). From the groundwater contour map, it was observed that groundwater moves toward the stream, indicating a gaining river system. Time series data from boreholes did 
Table 2. Physical and hydrological characteristics of the Kaap tributaries and outlet.

\begin{tabular}{lllll}
\hline Tributary name & $\begin{array}{l}\text { Kaap } \\
\text { outlet }\end{array}$ & Queens & $\begin{array}{l}\text { Upper } \\
\text { Suidkaap }\end{array}$ & Noordkaap \\
\hline Station ID & X2H022 & X2H008 & X2H031 & X2H010 \\
Reach length $(\mathrm{km})$ & 45.7 & 41.2 & 42.5 & 57.5 \\
Sub-basin area $\left(\mathrm{km}^{2}\right)$ & 1640 & 291 & 256 & 315 \\
Data analyzed & $1961-2012$ & $1949-2012$ & $1967-2012$ & $1970-2012$ \\
Period (years) & 51 & 63 & 45 & 42 \\
\% data missing & $5 \%$ & $0 \%$ & $3 \%$ & $6 \%$ \\
Highest flow measured HHQ $\left(\mathrm{m}^{3} \mathrm{~s}^{-1}\right)$ & 483 & 96 & 123 & 28 \\
Lowest flow measured NNQ $\left(\mathrm{m}^{3} \mathrm{~s}^{-1}\right)$ & 0 & 0 & 0 & 0 \\
Mean of yearly highest flows MHQ $\left(\mathrm{m}^{3} \mathrm{~s}^{-1}\right)$ & 65 & 13 & 19 & 6 \\
Mean of yearly lowest flows MNQ $\left(\mathrm{m}^{3} \mathrm{~s}^{-1}\right)$ & 0.4 & 0.1 & 0.3 & 0.2 \\
Mean flow MQ (m $\mathrm{s}^{-1}$ ) & 3.6 & 0.6 & 1.1 & 0.6 \\
Variability ratio & 180 & 186 & 65 & 31 \\
Specific discharge $\left(\mathrm{L} \mathrm{s}^{-1} \mathrm{Km}^{-1}\right)$ & 3.0 & 2.2 & 4.2 & 1.9 \\
Maximum and average days of no flow per year & $139 ; 8$ & $12 ; 1$ & $23 ; 1$ & $17 ; 1$ \\
\hline
\end{tabular}

not show a significant change in water tables due to seasonal or long-term changes.

\subsection{Spatial hydrochemical characterization}

The upstream rain sample average had a more depleted isotopic signature $\left(-5.1 \%\right.$ o for $\delta^{18} \mathrm{O} ;-30.2 \%$ or for $\left.\delta^{2} \mathrm{H}\right)$ than the lower-elevation rain sample average $\left(-4.4 \%\right.$ ofor $\delta^{18} \mathrm{O}$; $-24.7 \%$ for $\left.\delta^{2} \mathrm{H}\right)$. Upstream and downstream delta deuterium values ranged from a minimum of $-30.2 \%$ o to a maximum of $-21.8 \%$ and delta oxygen- 18 ranged from -5.14 to $-3.72 \%$. Baseflow at the catchment outlet (X2H022) was characterized by analyzing DWA long-term water quality data and by field sampling prior to the 2013-2014 rainy season. Results from the field sampling are shown in Table 3.

The upper section of the catchment, mainly dominated by granite, is characterized by low to moderate electrical conductivities. Long-term mean electrical conductivities (sampled monthly by the DWA from 1984 to 2012) for the upper Suidkaap and Noordkaap tributaries were 75 and $104 \mu \mathrm{S} \mathrm{cm}^{-1}$, respectively. On the contrary, the catchment outlet had a higher long-term average EC of $572 \mu \mathrm{S} \mathrm{cm}^{-1}$ (DWA long-term monthly average from 1977 to 2012).

\subsection{Rainfall-runoff observations}

Table 4 summarizes the rainfall-runoff observations for the four studied events. The events had distinctive characteristics showing large variability in peak flows, API, rainfall duration, rain depth and maximum and average intensities. Event 1 had the highest peak flow at $124 \mathrm{~m}^{3} \mathrm{~s}^{-1}$, while Event 3 had the smallest peak flow at $6.5 \mathrm{~m}^{3} \mathrm{~s}^{-1}$. APIs, especially $\mathrm{API}_{-7}$, differed from very wet conditions during Event $1(39 \mathrm{~mm})$ to very dry conditions $(1 \mathrm{~mm})$ during Event 2 . Event 1 was a relatively short event $(7 \mathrm{~h})$ with high
Table 3. List of mean values of hydrochemical parameters obtained during the 2013-2014 field campaign.

\begin{tabular}{lrrrr}
\hline & \multicolumn{4}{c}{ Location } \\
\cline { 2 - 5 } Parameter & Suidkaap & Queens & Noordkaap & Outlet \\
\hline $\mathrm{EC}\left(\mu \mathrm{S} \mathrm{cm}^{-1}\right)$ & 84.0 & 128.7 & 92.9 & 443.0 \\
$\mathrm{SiO}_{2}\left(\mathrm{mg} \mathrm{L}^{-1}\right)$ & 22.4 & 17.0 & 20.9 & 24.1 \\
$\mathrm{CaCO}_{3}\left(\mathrm{mg} \mathrm{L}^{-1}\right)$ & 38.5 & 59.5 & 41.3 & 154.0 \\
$\mathrm{Cl}\left(\mathrm{mg} \mathrm{L}^{-1}\right)$ & 3.8 & 3.6 & 2.8 & 15.5 \\
$\mathrm{SO}_{4}\left(\mathrm{mg} \mathrm{L}^{-1}\right)$ & 1.8 & 4.1 & 1.6 & 47.2 \\
$\mathrm{Na}_{\left(\mathrm{mg} \mathrm{L}^{-1}\right)}$ & 7.5 & 7.1 & 7.3 & 29.3 \\
$\mathrm{Mg}\left(\mathrm{mg} \mathrm{L}^{-1}\right)$ & 2.8 & 7.4 & 3.7 & 25.3 \\
$\mathrm{Ca}\left(\mathrm{mg} \mathrm{L}^{-1}\right)$ & 7.9 & 9.1 & 6.8 & 27.6 \\
$\delta^{2} \mathrm{H}(\% \circ$ VSMOW $)$ & -12.1 & -12.4 & -12.7 & -8.9 \\
$\delta^{18} \mathrm{O}(\% \circ$ VSMOW $)$ & -3.2 & -3.1 & -3.5 & -2.7 \\
\hline
\end{tabular}

antecedent precipitation conditions and high rain intensities generating the largest amount of runoff at the outlet. In contrast, Event 3 was a short event with average rain intensity that generated the lowest peak flow.

\subsection{Response of isotopes and hydrochemical parameters}

During the storm events, most hydrochemical parameters (EC, $\mathrm{Ca}, \mathrm{Mg}, \mathrm{Na}, \mathrm{SiO}_{2}$ and $\left.\mathrm{Cl}\right)$ and water isotopes $\left(\delta^{2} \mathrm{H}\right.$ and $\delta^{18} \mathrm{O}$ ) showed dilution responses, except for potassium (Fig. 7). The first flood was the largest event sampled, reaching a peak flow of $124 \mathrm{~m}^{3} \mathrm{~s}^{-1}$ where a larger contribution of direct runoff was observed. In this event, a larger degree of dilution of the sampled hydrochemical parameters is also observed. The following events had smaller peak flows of 27.6, 6.5 , and $7.1 \mathrm{~m}^{3} \mathrm{~s}^{-1}$ for Events 2, 3, and 4, respectively. Thus, smaller dilution effects were observed for Events 2, 3, and 4. 
Table 4. Rainfall-runoff relationships observed during the 2013-2014 wet season for the Kaap catchment at the outlet (X2H022 stream gauge) and average precipitation from Koffiekultuur, Nelshoogte Bos, Satico, and the Josefdal border rain stations.

\begin{tabular}{|c|c|c|c|c|c|}
\hline & & Event 1 & Event 2 & Event 3 & Event 4 \\
\hline \multirow[t]{5}{*}{ Runoff } & Peak flow time and date & 13 Dec 2013, 18:24 & 30 Dec 2013, 06:12 & 16 Jan 2014, 03:48 & 31 Jan $2014,17: 00$ \\
\hline & Maximum river depth (m) & 2.0 & 1.0 & 0.5 & 0.5 \\
\hline & Peak flow $\left(\mathrm{m}^{3} \mathrm{~s}^{-1}\right)$ & 124.0 & 27.6 & 6.5 & 7.1 \\
\hline & Runoff volume (mm) & 3.2 & 2.6 & 0.1 & 0.4 \\
\hline & Time to peak after rainfall started (h) & 24.4 & 31.2 & 60.8 & 22.0 \\
\hline \multirow[t]{8}{*}{ Rainfall } & Rain start date and time & 12 Dec 2013, 18:00 & 28 Dec 2013, 23:00 & 13 Jan $2014,15: 00$ & $30 \operatorname{Jan} 2014,19: 00$ \\
\hline & Rain duration (h) & 7 & 39 & 7 & 26 \\
\hline & Rain depth (mm) & 24 & 78 & 17 & 20 \\
\hline & Average rain intensity $\left(\mathrm{mm} \mathrm{h}^{-1}\right)$ & 3.4 & 2.0 & 2.5 & 0.8 \\
\hline & Maximum rain intensity $\left(\mathrm{mm} \mathrm{h}^{-1}\right)$ & 9.8 & 12 & 5 & 10 \\
\hline & Antecedent Precipitation Index API_-7 (mm) & 38.7 & 1.3 & 7.8 & 24.9 \\
\hline & API $_{-14}(\mathrm{~mm})$ & 118.1 & 12.8 & 20.0 & 67.9 \\
\hline & API_-30 (mm) & 390.2 & 220.8 & 192.4 & 223.8 \\
\hline
\end{tabular}
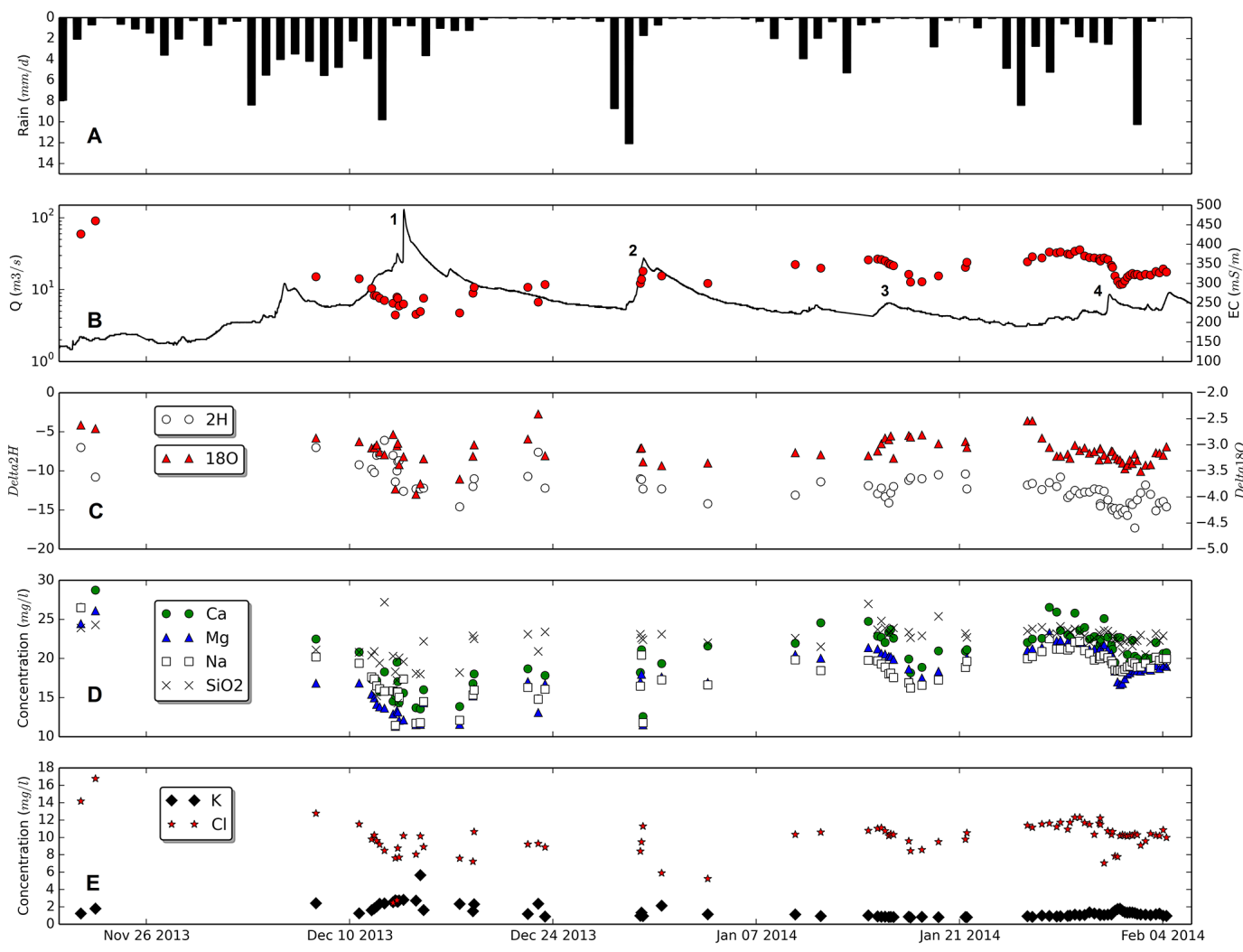

Figure 7. Kaap catchment: (a) average precipitation in $\mathrm{mm} \mathrm{day}^{-1}$, (b) discharge at the outlet in $\mathrm{m}^{3} \mathrm{~s}^{-1}$ and electrical conductivity $\mu \mathrm{S} \mathrm{cm}{ }^{-1}$, (c) delta deuterium and delta oxygen-18 in \% VSMOW, (d) calcium, magnesium, sodium and silica concentrations at the outlet in mg $\mathrm{L}^{-1}$, and (e) chloride and potassium concentrations at the outlet in $\mathrm{mg} \mathrm{L}^{-1}$.

The smaller peak flows and lower direct runoff contributions for the latter events may explain the temporal variability observed in the increased concentrations of the hydrochemical parameters over time. During Event 1, EC's initial value of $317 \mu \mathrm{S} \mathrm{cm}^{-1}$ decreased to $247 \mu \mathrm{S} \mathrm{cm}^{-1}$ during peak flow. Similarly, $\mathrm{CaCO}_{3}$ and $\mathrm{SiO}_{2}$ decreased from
115 to $82 \mathrm{mg} \mathrm{L}^{-1}$ and from 21.1 to $19.6 \mathrm{mg} \mathrm{L}^{-1}$, respectively. $\delta^{18} \mathrm{O}(-2.9 \% \circ)$ and $\delta^{2} \mathrm{H}(-7.0 \% \circ)$ decreased to -3.2 and $-12.6 \%$ o, respectively. Potassium concentrations increased from 1.3 to $2.8 \mathrm{mg} \mathrm{L}^{-1}$. For Event 2, a smaller number of samples were collected due to malfunctions of the automatic sampler. However, dilution of $\mathrm{SiO}_{2}$ and $\mathrm{Cl}$, and an increase 
Table 5. Percentages of direct runoff (DR) and groundwater (GW) contributions and $70 \%$ uncertainty percentages ( $W$ ) from two-component hydrograph separations for the 2013-2014 wet season, Kaap catchment, South Africa.

\begin{tabular}{|c|c|c|c|c|c|c|c|c|c|c|c|c|}
\hline \multirow[t]{2}{*}{ Tracer } & \multicolumn{3}{|c|}{ Event 1} & \multicolumn{3}{|c|}{ Event 2} & \multicolumn{3}{|c|}{ Event 3} & \multicolumn{3}{|c|}{ Event 4} \\
\hline & DR & GW & $W$ & DR & GW & $W$ & DR & GW & $W$ & DR & GW & $W$ \\
\hline EC & 22 & 78 & 6.8 & 5 & 95 & 7.9 & 6 & 94 & 7.0 & 27 & 73 & 4.2 \\
\hline $\mathrm{SiO}_{2}$ & 21 & 79 & 2.6 & 6 & 94 & 2.5 & 12 & 88 & 2.2 & 21 & 79 & 2.6 \\
\hline $\mathrm{CaCO}_{3}$ & 29 & 71 & 6.3 & 9 & 91 & 6.9 & 6 & 94 & 6.8 & 24 & 76 & 4.6 \\
\hline $\mathrm{Mg}$ & 22 & 78 & 5.6 & 13 & 87 & 6.0 & 8 & 92 & 5.3 & 24 & 76 & 4.0 \\
\hline${ }^{18} \mathrm{O}$ & 23 & 77 & 8.6 & 8 & 92 & 3.3 & 10 & 90 & 3.1 & 36 & 64 & 12.4 \\
\hline${ }^{2} \mathrm{H}$ & 19 & 81 & 5.6 & 5 & 95 & 15.0 & 2 & 98 & 19.4 & 21 & 79 & 24.9 \\
\hline
\end{tabular}
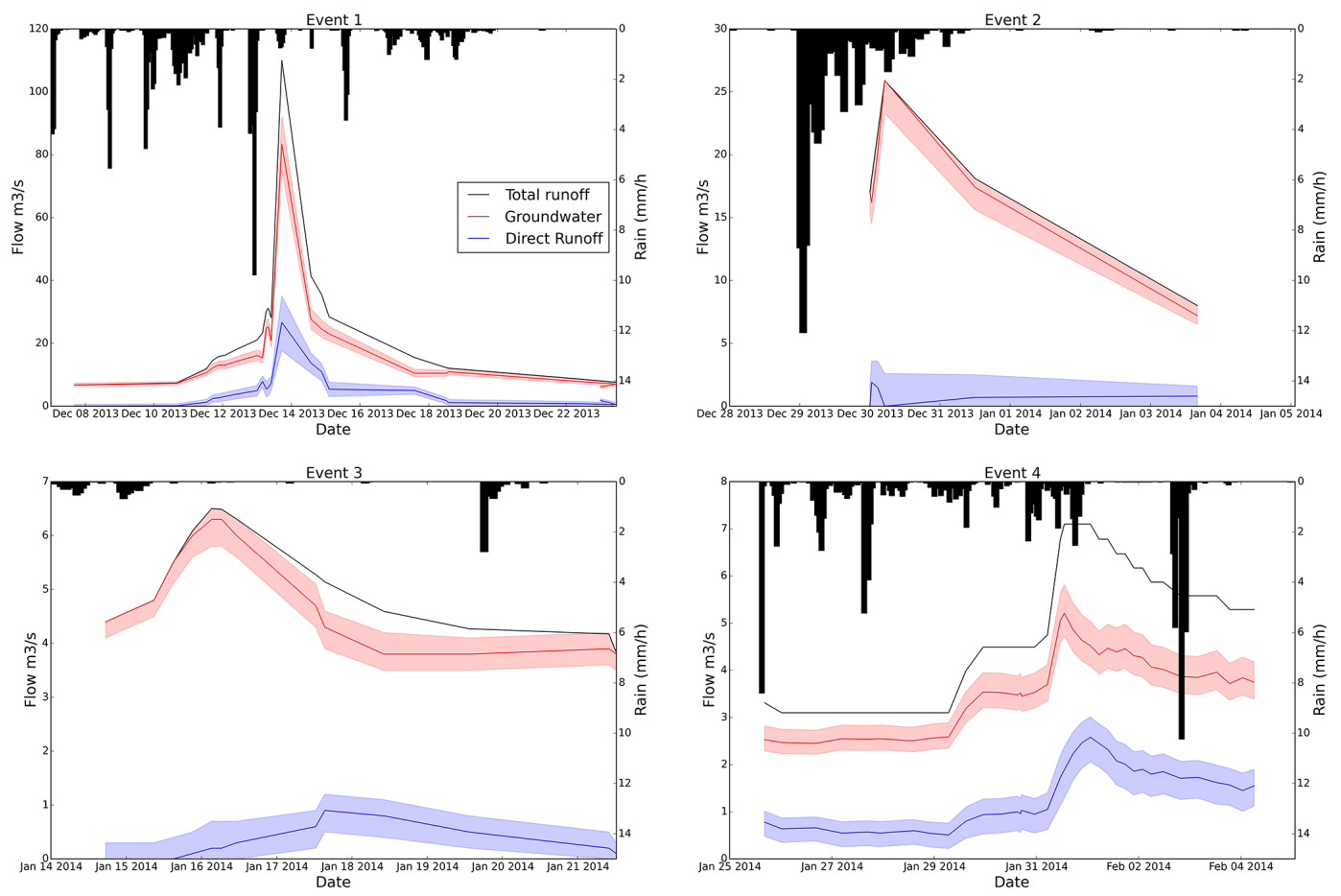

Figure 8. Two-component hydrograph separations using electrical conductivity as a tracer. Events 1 and 4 had a larger direct runoff contribution coinciding with the total runoff peak. Events 2 and 3 had a smaller direct runoff contribution.

in potassium concentrations, were observed. Events 3 and 4 were smaller events, but a smaller sampling interval showed the same dilution behavior of the sampled parameters and the increase in potassium concentrations.

\subsection{Two-component hydrograph separation}

Event and pre-event components were separated using $\delta^{18} \mathrm{O}$ and $\delta^{2} \mathrm{H}$, and direct runoff and groundwater were separated using $\mathrm{EC}, \mathrm{SiO}^{2}, \mathrm{CaCO}_{3}$, and $\mathrm{Mg}$. For simplicity, the twocomponent hydrograph separation components in this study are referred to as direct runoff and groundwater components. Direct runoff (quick-flow component), defined in the methods section as the portion of direct precipitation and infiltration excess overland flow, was characterized using the rain samples collected upstream and downstream inside the catchment. Groundwater end-members were obtained from the initial streamwater samples before the rainfall started. Events 1 and 4 had the largest contributions of direct runoff among the four events, accounting for $29 \%$ in the case of Event 1 and up to $36 \%$ for Event 4 (Table 5). Events 2 and 3 had lower direct runoff contributions ranging from 5 to $13 \%$ for Event 2 and 2 to $12 \%$ for Event 3. Figure 8 shows the two-component hydrograph separations for the four events.

\subsection{Isotope hydrograph separation versus hydrochemical hydrograph separation}

Hydrochemical tracers usually separate runoff from source areas, while isotopes generally separate old water from new 


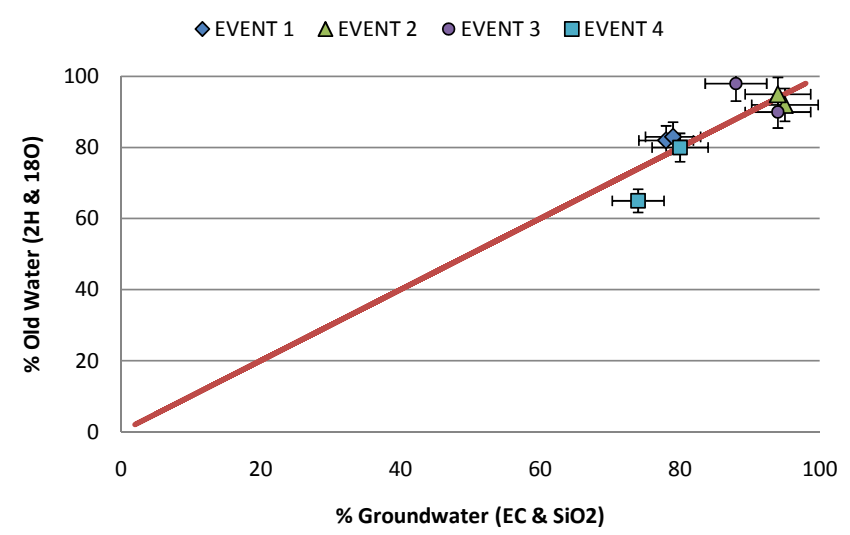

Figure 9. Percentages of groundwater and old water contributions using environmental isotopes $\left(\delta^{2} \mathrm{H}\right.$ and $\left.\delta^{18} \mathrm{O}\right)$ and hydrochemical (EC and $\mathrm{SiO}_{2}$ ) tracers.

water. The definition of Klaus and McDonnell (2013) was used for this study, stating that pre-event water (or old water as referred to in this section of the study) is the water stored in the catchment before the rainfall event. This component may not be representative of deep groundwater sources, but it may be water stored from the same rainfall season but from previous rainfall events. Thus, a comparison between "oldwater" and "groundwater" components obtained during the four events was carried out to investigate to what extent these components are similar. This allowed us to determine the suitability of isotopic hydrograph separations versus hydrochemical separations for semi-arid environments. Figure 9 presents the percentages of groundwater and old-water contributions using environmental isotopes $\left(\delta^{2} \mathrm{H}\right.$ and $\left.\delta^{18} \mathrm{O}\right)$ and hydrochemical (EC, $\mathrm{SiO}_{2}, \mathrm{CaCO}_{3}$, and $\mathrm{Mg}$ ) tracers for the four investigated events. It is noted that Events 1 and 4 have smaller contributions of groundwater than Events 3 and 4. During Event 4 and Event 2, old water resembles groundwater. The data points above the line present instances where old water is not necessarily groundwater, but water stored before the event. No major differences are observed from using hydrochemical or isotope tracers for the hydrograph separation.

\subsection{End-member mixing analysis (EMMA)}

To further differentiate the runoff components, a principal component analysis (PCA) was carried out on 12 solutes (EC, $\mathrm{SiO}_{2}, \mathrm{CaCO}_{3}, \mathrm{Cl}, \mathrm{NO}_{3}-\mathrm{N}, \mathrm{SO}_{4}, \mathrm{Na}, \mathrm{Mg}, \mathrm{K}, \mathrm{Ca}, \delta^{18} \mathrm{O}$, and $\delta^{2} \mathrm{H}$ ) using the $\mathrm{R}$ statistical software (R Development Core Team, 2014). The correlation matrix was used for the PCA. Results indicated that $90 \%$ of the variability is explained by two principal components $(m)$. Thus, the number of end-members $(n)$ can be chosen as $n=m+1$, leading to a three-component hydrograph separation (Christophersen and Hooper, 1992). Figure 10 shows the biplot of principal components where the orthogonal vectors indicate

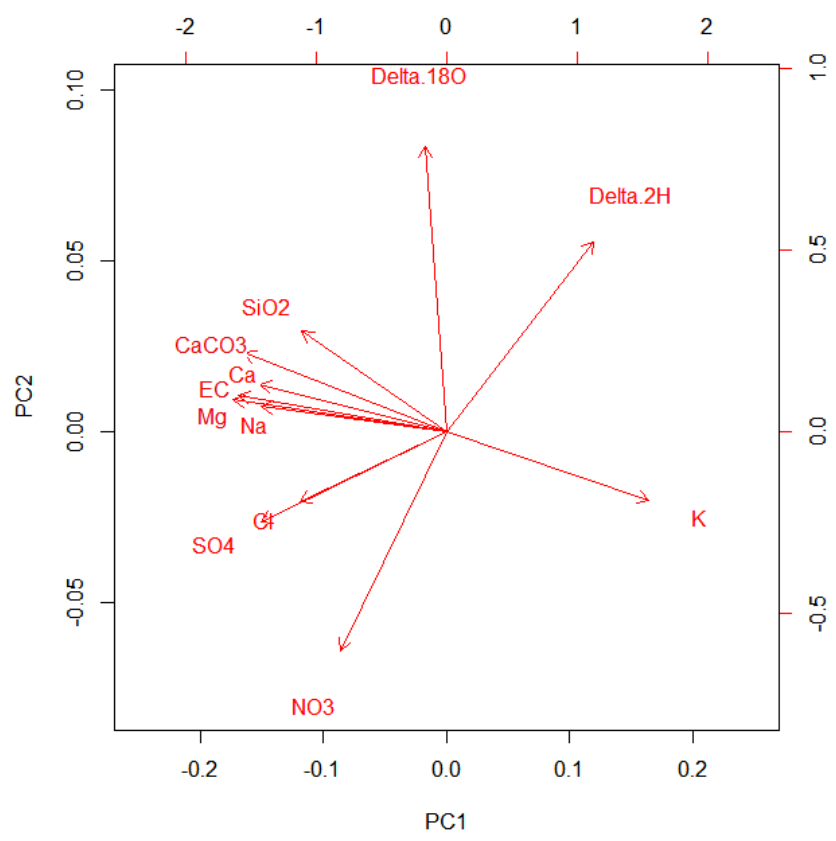

Figure 10. Biplot of principal components generated during PCA of streamwater samples using $\mathrm{EC}, \mathrm{SiO}_{2}, \mathrm{CaCO}_{3}, \mathrm{Cl}, \mathrm{NO}_{3}-\mathrm{N}, \mathrm{SO}_{4}$, $\mathrm{Na}, \mathrm{Mg}, \mathrm{K}, \mathrm{Ca}, \delta^{2} \mathrm{H}$, and $\delta^{18} \mathrm{O}$.

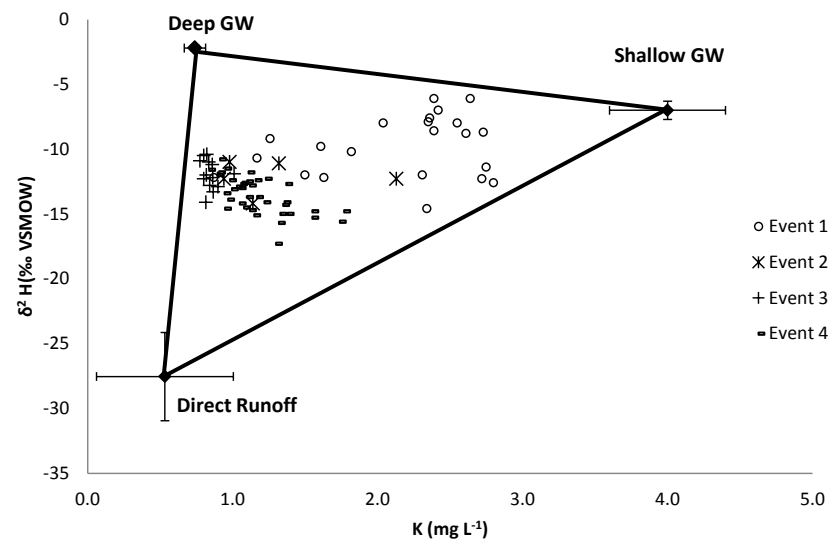

Figure 11. Mixing diagram of $\delta^{2} \mathrm{H}$ and $\mathrm{K}$ showing streamwater samples at the outlet for four rain events during the 2013-2014 wet season.

no dependency between parameters. This is observed for $\delta^{18} \mathrm{O}, \delta^{2} \mathrm{H}, \mathrm{K}$, and $\mathrm{NO}_{3}$. The clustering of the hydrochemical parameters reveals the strong correlation between these parameters $\left(\mathrm{SiO}_{2}, \mathrm{CaCO}_{3}, \mathrm{Ca}, \mathrm{EC}, \mathrm{Mg}, \mathrm{Na}, \mathrm{Cl}\right.$, and $\left.\mathrm{SO}_{4}\right)$. Potassium shows a negative strong correlation with the clustered parameters but not with the water isotopes and $\mathrm{NO}_{3}$. Thus, for the three-component hydrograph separations, orthogonal vectors with weak Pearson correlations were selected. These are $\mathrm{K}$ and $\delta^{18} \mathrm{O}(r=-0.28)$ and $\mathrm{K}$ and $\delta^{2} \mathrm{H}$ $(r=0.45)$. The latter shown in Fig. 11. Nitrate was not selected due to its non-conservative properties. Potassium was identified as a useful tracer due to its increasing concentra- 
Table 6. Direct runoff $(\mathrm{DR})$, shallow groundwater $\left(\mathrm{GW}_{\mathrm{S}}\right)$, and deep groundwater $\left(\mathrm{GW}_{\mathrm{D}}\right)$ contributions in $\%$ and $70 \%$ uncertainty of threecomponent hydrograph separations in $\%$.

\begin{tabular}{|c|c|c|c|c|c|c|c|c|c|c|c|c|}
\hline \multirow[t]{2}{*}{ Tracers } & \multicolumn{3}{|c|}{ Event 1} & \multicolumn{3}{|c|}{ Event 2} & \multicolumn{3}{|c|}{ Event 3} & \multicolumn{3}{|c|}{ Event 4} \\
\hline & DR & $\mathrm{GW}_{\mathrm{S}}$ & $\mathrm{GW}_{\mathrm{D}}$ & DR & $\mathrm{GW}_{\mathrm{S}}$ & $\mathrm{GW}_{\mathrm{D}}$ & $\mathrm{DR}$ & $\mathrm{GW}_{\mathrm{S}}$ & $\mathrm{GW}_{\mathrm{D}}$ & $\mathrm{DR}$ & $\mathrm{GW}_{\mathrm{S}}$ & $\mathrm{GW}_{\mathrm{D}}$ \\
\hline $\mathrm{K}$ and ${ }^{18} \mathrm{O}$ & 28 & 45 & 26 & 7 & 19 & 74 & 16 & 6 & 78 & 41 & 21 & 37 \\
\hline $70 \%$ uncertainty $(\%)$ & 7.2 & 5.3 & 5.8 & 7.4 & 3.2 & 5.1 & 5.3 & 3.0 & 3.9 & 7.9 & 6.2 & 5.8 \\
\hline $\mathrm{K}$ and ${ }^{2} \mathrm{H}$ & 22 & 45 & 33 & 14 & 19 & 67 & 11 & 5 & 84 & 37 & 20 & 42 \\
\hline $70 \%$ uncertainty $(\%)$ & 4.8 & 6.6 & 6.4 & 3.8 & 3.9 & 5.5 & 3.0 & 2.8 & 4.0 & 6.3 & 6.2 & 7.6 \\
\hline
\end{tabular}
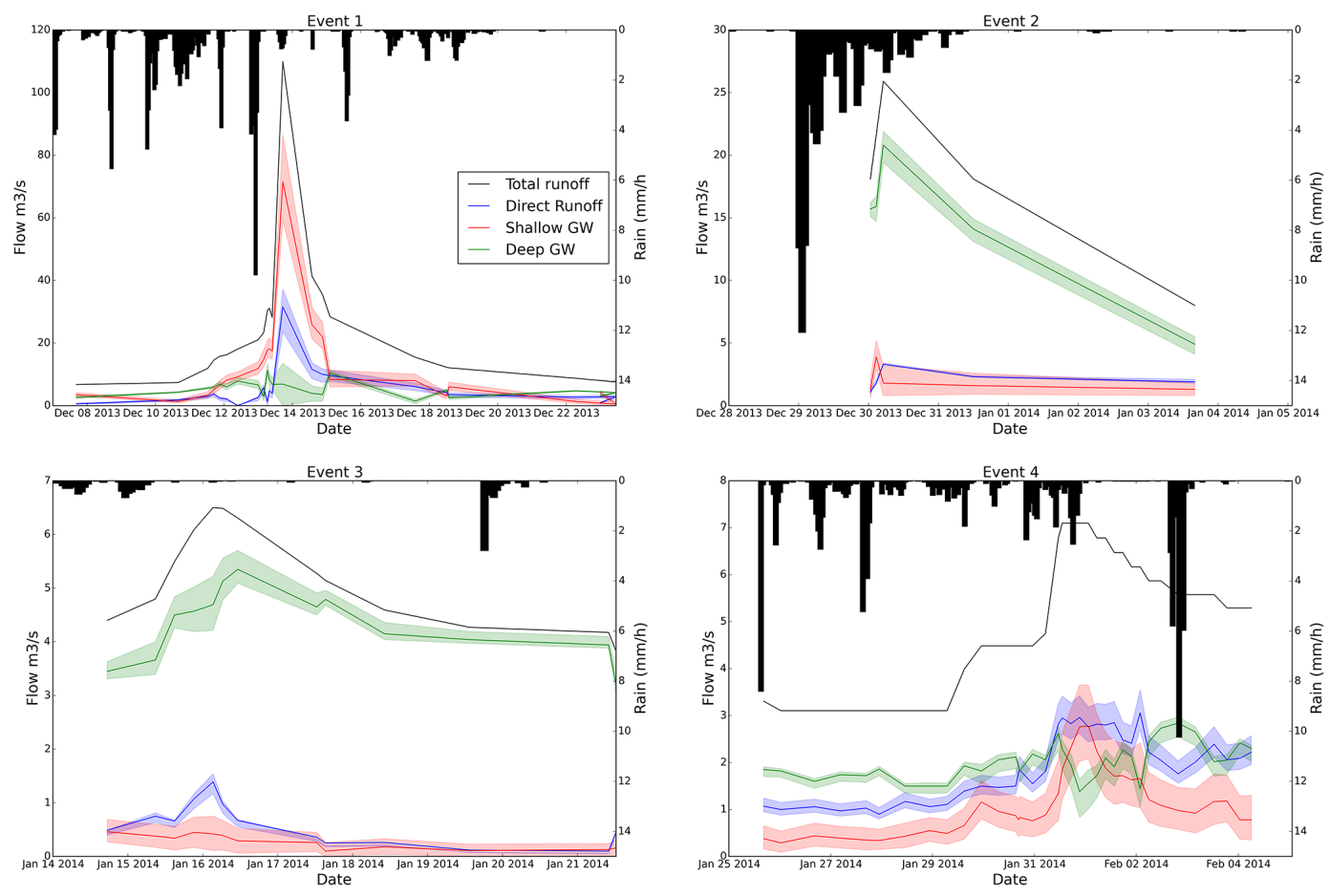

Figure 12. Three-component hydrograph separations using $\mathrm{K}$ and ${ }^{2} \mathrm{H}$.

tions during runoff peaks. This high potassium concentration suggested the presence of soil water influenced by mobilization of fertilizer and/or organic material. To account for additional near-surface water, this component is referred to as the "shallow groundwater component" during this study. It is important to note that the shallow groundwater component could be a mix of surface runoff and near-surface water since potassium was used as an indicator of shallow groundwater, and this element can also be found in surface runoff.

\subsection{Three-component hydrograph separation}

Direct runoff contributions obtained during the threecomponent hydrograph separations (Table 6 and Fig. 12) concur with the two-component hydrograph separations. Events 1 and 4 were characterized by higher contributions of direct runoff than Events 2 and 3. Moreover, Event 1 also had a higher contribution of shallow groundwater that peaked during the total runoff peak. Events 2, 3, and 4 had higher deep groundwater contributions. Uncertainties for the threecomponent hydrograph separations can be seen in Table 6 .

\section{Discussion}

\subsection{Runoff processes in the Kaap catchment}

From the mixing diagrams, groundwater analysis and spatial hydrochemical characterization of the catchment, the runoff components were identified and characterized. The groundwater analysis suggested two sources of groundwater of different ionic content at the upper and lower sections of the catchment. In the upstream area, granite is the dominant formation explaining the lower ionic content in groundwater, in contrast to the downstream areas, where geologically diverse 
Table 7. Runoff studies with the number of events studied.

\begin{tabular}{|c|c|c|}
\hline Study name & Reference & $\begin{array}{l}\text { Number of } \\
\text { events }\end{array}$ \\
\hline Hydrograph separation using stable isotopes, silica and electrical conductivity: an alpine example & Laudon and Slaymaker (1997) & 5 \\
\hline $\begin{array}{l}\text { The role of soil water in stormflow generation in a forested headwater catchment: synthesis of } \\
\text { natural tracer and hydrometric evidence }\end{array}$ & Bazemore et al. (1994) & 2 \\
\hline $\begin{array}{l}\text { Quantifying contributions to storm runoff through end-member mixing analysis and hydrologic } \\
\text { measurements at the Panola Mountain Research Watershed (Georgia, USA) }\end{array}$ & Burns et al. (2001) & 2 \\
\hline $\begin{array}{l}\text { On the value of combined event runoff and tracer analysis to improve understanding of catchment } \\
\text { functioning in a data-scarce semi-arid area }\end{array}$ & Hrachowitz et al. (2011) & 28 \\
\hline $\begin{array}{l}\text { Quantifying uncertainties in tracer-based hydrograph separations: a case study for two-, three- and } \\
\text { five-component hydrograph separations in a mountainous catchment }\end{array}$ & Uhlenbrook and Hoeg (2003) & 4 \\
\hline Hydrograph separations in a mesoscale mountainous basin at event and seasonal timescales & Uhlenbrook et al. (2002) & 2 \\
\hline $\begin{array}{l}\text { Identification of runoff generation processes using combined hydrometric, tracer and geophysical } \\
\text { methods in a headwater catchment in South Africa }\end{array}$ & Wenninger et al. (2008) & 3 \\
\hline $\begin{array}{l}\text { Runoff generation in a steep, tropical montane cloud forest catchment on permeable } \\
\text { volcanic substrate }\end{array}$ & $\begin{array}{l}\text { Muñoz-Villers and McDonnell } \\
\text { (2012) }\end{array}$ & 13 \\
\hline Quantifying the relative contributions of riparian and hillslope zones to catchment runoff & McGlynn and McDonnell (2003) & 2 \\
\hline $\begin{array}{l}\text { Dynamics of nitrate and chloride during storm events in agricultural catchments } \\
\text { with different subsurface drainage intensity (Indiana, USA) }\end{array}$ & Kennedy et al. (2012) & 2 \\
\hline $\begin{array}{l}\text { Investigation of hydrological processes using chemical and isotopic tracers in a } \\
\text { mesoscale Mediterranean forested catchment during autumn recharge }\end{array}$ & Marc et al. (2001) & 3 \\
\hline
\end{tabular}

formations and land use increase the ionic content of groundwater. The weathered granite layer allows rain to infiltrate to the deeper groundwater reservoir through preferential flowpaths with less contact time for weathering processes to occur. This explains the hydrochemical signature of the deep groundwater component, which is characterized by its moderate electrical conductivities, moderate to high dissolved silica, lower ionic content, and low potassium concentrations. The chemical signature of the shallow groundwater component is characterized by the high electrical conductivities, alkalinity, sulfates, potassium, and nitrates that are washed from top geological layers with large ionic content and land uses such as agriculture and mining that are more predominant in the downstream region of the catchment.

The three-component hydrograph separations suggest that the shallow groundwater component (potentially including surface runoff) is quickly activated during rainfall events, and its contribution increases as the antecedent precipitation increases as observed during Events 1 and 4, where the shallow groundwater contributions were 45 and 20-21\%, respectively. Moreover, a connection between surface and groundwater is evident from the groundwater contour map (Fig. 2d), which shows a gaining river system, and from the flow duration curves, which indicate exfiltrating groundwater storages to the streams. Further literature (Hughes, 2010) suggests that most of South Africa's groundwater is stored in secondary aquifers and that surface flow may be nourished by lateral flow from semi-saturated fracture systems after storm events.

Other studies (Petersen, 2012) in the nearby Kruger National Park (KNP) have shown that groundwater recharge occurs mostly during the wet season and groundwater flow travels in accordance with the topographical relief. Petersen (2012) studied a granite-dominated area and a basalticrock-dominated area, approximately $30 \mathrm{~km}$ east of the Kaap outlet. The study found that the granite region was mainly characterized by the steep topography, which favors overland flow that infiltrates through depressions, cracks and fractures by preferential pathways, while the southern basaltic section with a flatter topography showed piston flow processes to be more predominant. The Petersen (2012) findings, covering studies of approximately 1011 boreholes in the KNP, support the findings in the Kaap catchment where high fracturing in the granite section allows recharge of deeper groundwater reservoirs through preferential flowpaths.

It is important to note that the inferences drawn from this study are based on four events sampled during the 20132014 wet season but supported by historical meteorological, hydrological and water quality data, groundwater analysis and a spatial hydrochemical study of the catchment. In addition, Table 7 shows runoff studies with a similar number of events studied. 


\subsection{The catchment's response dependency on antecedent precipitation}

Hydrograph separation results suggested that there is a direct runoff contribution (2-36\%) to total runoff during storm events for the Kaap River. Similar results have been obtained for other catchments in semi-arid areas. For instance, Hrachowitz et al. (2011) in their study in four nested catchments in Tanzania found event runoff coefficients of 0.09. Similarly, Munyaneza et al. (2012) found groundwater contributions up to $80 \%$ of total runoff in the Mingina catchment in Rwanda during the two- and three-hydrograph separations in a $258 \mathrm{~km}^{2}$ catchment. The importance of subsurface flow in semi-arid catchments is also illustrated in Wenninger et al. (2008) in the Weatherley catchment in the Eastern Cape in South Africa.

From the several variables considered such as geology, topography and rainfall characteristics studied for the four events, the direct runoff component was most sensitive to the API. This is observed during Events 1 and 4, where API-7 values are the largest among the four events and direct runoff contributions are also the largest for these events. The relationship between $\mathrm{API}_{-7}$ and direct runoff generation is supported by a strong Pearson correlation (0.76-0.94). This suggests that direct runoff is enhanced by wetter conditions in the catchment due to saturation in the subsurface triggering saturation overland flow.

\subsection{Complexities of runoff process understanding in semi-arid areas}

The combination of climatic and hydrological processes influenced by topography, geology, soils and land use makes catchments complex systems. Although the opposite may be true for particular situations, in general, catchments become more non-linear as aridity increases and runoff processes become more spatially and temporally heterogeneous than in humid regions (Blöschl et al., 2013; Farmer et al., 2003). Thus, understanding hydrological processes in arid catchments becomes more difficult due to high variability of rainfall and streamflow, high evaporation losses, long infiltration pathways, permeable stream channel beds and often deep groundwater reservoirs (Hughes, 2007; Trambauer et al., 2013).

The high variability of rainfall enhances the difficulties of runoff prediction by triggering different runoff responses. For instance, high-intensity storms tend to generate overland flow in the form of infiltration excess overland flow (Smith and Goodrich, 2006), while high antecedent precipitation conditions enhance saturation excess overland flow. This effect is visible in this study during Event 1, where the high API suggested saturation of the subsurface, thus reducing the infiltration capacity and enhancing saturation excess overland flow. The opposite is observed for Events 2 and 3, where the low soil moisture conditions allow more rainfall to infiltrate, activating other runoff processes such as preferential vertical flow.

Although not included in this study, inter-annual variability, evaporation, hydraulic connectivity, permeable stream beds and interception have been shown to change the behavior of runoff processes in arid and semi-arid areas. For instance, inter-annual rainfall variability is closely related to high evaporation losses. The Mostert et al. (1993) study in a Namibian basin found that during wetter seasons, vegetation cover and total evaporation increased, thus reducing the amount of runoff reaching the outlet. Similarly, hydraulic connectivity in arid environments is limited by the reduced soil moisture conditions in these areas, leading to reduced groundwater recharge. Other fluxes such as interception and flow through permeable stream beds pose a greater challenge to the understanding of runoff processes in semi-arid areas. Interception can further decrease the hydrologic connectivity, breaking the link between meteoric water and groundwater as observed in the Zhulube catchment in Zimbabwe, where interception accounted for up to $56 \%$ of rainfall during the dry season (Love et al., 2010). Similarly, transmission losses due to the high degree of fracturing of stream beds can significantly reduce streamflow but increase recharge of groundwater systems.

Thus, this study illustrated the effects of temporal rainfall variability during the wet season, suggesting the influence of antecedent precipitation conditions on direct runoff generation. However, studying the effects of spatial and interannual rainfall variability, high evaporation and transpiration (from unsaturated zones, alluvial aquifers, and riparian zones) fluxes, the spatial variability of vegetation, and deep groundwater resources on streamflow generation is still required for better understanding of runoff processes in semi-arid areas. More monitoring of groundwater levels and aquifers would assist in bridging this gap of knowledge, such as in Van Wyk et al. (2012). Emphasis is placed on studying the region during dry weather for further understanding of evaporation and transpiration from deeper layers of soil moisture that in some cases can reach even into groundwater systems (e.g., eucalyptus trees).

\section{Conclusions}

The Kaap catchment has suffered devastating floods that affect greatly the trans-boundary Incomati Basin, in particular downstream areas in South Africa, Swaziland and Mozambique, where recent floods have caused significant economic and social losses. Runoff processes were poorly understood in the Kaap catchment, limiting rainfall-runoff models to lead to better informed water management decisions. Through hydrometric measurements, tracers and groundwater observations, runoff components and main runoff generation processes were identified and quantified in the Kaap catchment for the 2013-2014 wet season. The suitability of 
isotope hydrograph separation was tested by comparing it to hydrochemical hydrograph separations showing no major differences between these tracers. Hydrograph separations showed that groundwater was the dominant runoff component for the 2013-2014 wet season. Three component hydrograph separations suggested a third component that we addressed as the shallow groundwater component. However, further research is still necessary to make a clear distinction between surface runoff and shallow groundwater. A strong correlation between direct runoff generation and antecedent precipitation conditions was found for the studied events. Direct runoff was enhanced by high antecedent precipitation activating saturation excess overland flow. Similar groundwater contributions have been observed in other studies in semiarid areas (Hrachowitz et al., 2011; Munyaneza et al., 2012; Wenninger et al., 2008). The understanding of runoff generation mechanisms in the Kaap catchment contributes to the limited number of hydrological process studies and in particular hydrograph separation studies in semi-arid regions for the proper management of water resources. Moreover, this study was carried out during the wet season, and in order to gather a better understanding of the hydrological system, further studies focusing on the dry season are still needed, particularly on the dependency of runoff generation on soil moisture and vegetation.

Acknowledgements. This study was carried out under the umbrella of the RISK-based Operational water MANagement for the Incomati River basin (RISKOMAN) project. The authors would like to thank the RISKOMAN partners, UNESCO-IHE, Universidade Eduardo Mondlane (Mozambique), University of KwaZulu-Natal (UKZN, South Africa), the Komati River Basin Authority (Swaziland) and Incomati-Usuthu Catchment Management Agency (IUCMA, South Africa), for their financial and technical cooperation. This research has also been supported by the International Foundation for Science (IFS) Stockholm, Sweden, through a grant (W/5340-1) to Aline M. L. Saraiva Okello. Gratitude is also expressed to Ilyas Masih (UNESCO-IHE), Thomas Gyedu Ababio (IUCMA), Graham Jewitt (UKZN), Cobus Pretorius (UKZN), Eddie Riddell (SANParks), Gareth Bird (Independent), the ICMA staff, In-Situ Groundwater Consulting, IAEA, UNESCO-IHE laboratory staff, and the advanced class program at UNESCO-IHE funded by UNEP-DHI.

Edited by: A. Bronstert

\section{References}

Allen, R. G., Pereira, L. S., Raes, D., and Smith, M.: Crop evapotranspiration - Guidelines for computing crop water requirements, FAO Irrigation and drainage paper 56, Food and Agriculture Organization of the United Nations, Rome, 1998.

Bazemore, D. E., Eshleman, K. N. and Hollenbeck, K. J.: The Role of Soil-Water in Stormflow Generation in a Forested Headwater Catchment - Synthesis of Natural Tracer and Hydro- metric Evidence, J. Hydrol., 162, 47-75, doi:10.1016/00221694(94)90004-3, 1994.

Blöschl, G., Sivapalan, M., Wagener, T., Viglione, A., and Savenije, H.: Runoff prediction in ungauged basins, Cambridge University Press, 2013.

Burns, D. A., McDonnell, J. J., Hooper, R. P., Peters, N. E., Freer, J. E., Kendall, C., and Beven, K.: Quantifying contributions to storm runoff through end-member mixing analysis and hydrologic measurements at the Panola Mountain Research Watershed (Georgia, USA), Hydrol. Process., 15, 1903-1924, doi:10.1002/Hyp.246, 2001.

Burns, D. A.: Stormflow-hydrograph separation based on isotopes: the thrill is gone - what's next?, Hydrol. Process., 16, 15151517, doi:10.1002/Hyp.5008, 2002.

Camarasa-Belmonte, A. M. and Soriano, J.: Empirical study of extreme rainfall intensity in a semi-arid environment at different time scales, J. Arid Environ., 100-101, 63-71, 2014.

Christophersen, N. and Hooper, R. P.: Multivariate-Analysis of Stream Water Chemical-Data - the Use of Principal Components-Analysis for the End-Member Mixing Problem, Water Resour. Res., 28, 99-107, doi:10.1029/91wr02518, 1992.

de Wit, M. J., Furnes, H., and Robins, B.: Geology and tectonostratigraphy of the Onverwacht Suite, Barberton Greenstone Belt, South Africa, Precambrian Res., 168, 1-27, 2011.

Farmer, D., Sivapalan, M., and Jothityangkoon, C.: Climate, soil, and vegetation controls upon the variability of water balance in temperate and semiarid landscapes: Downward approach to water balance analysis, Water Resour. Res., 39, 1035, doi:10.1029/2001WR000328, 2003.

Genereux, D.: Quantifying uncertainty in tracer-based hydrograph separations, Water Resour. Res., 34, 915-919, doi:10.1029/98wr00010, 1998.

GRIP: Groundwater Resources Information Programme, Polokwane, South Africa, 2012.

Gröning, M., Lutz, H. O., Roller-Lutz, Z., Kralik, M., Gourcy, L., and Pöltenstein, L.: A simple rain collector preventing water reevaporation dedicated for ${ }^{18} \mathrm{O}$ and Deuterium analysis of cumulative precipitation samples, J. Hydrol., 448-449, 195-200, 2012.

Hrachowitz, M., Soulsby, C., Tetzlaff, D., Dawson, J. J. C., Dunn, S. M., and Malcolm, I. A.: Using long-term data sets to understand transit times in contrasting headwater catchments, J. Hydrol., 367, 237-248, doi:10.1016/j.jhydrol.2009.01.001, 2009.

Hrachowitz, M., Bohte, R., Mul, M. L., Bogaard, T. A., Savenije, H. H. G., and Uhlenbrook, S.: On the value of combined event runoff and tracer analysis to improve understanding of catchment functioning in a data-scarce semi-arid area, Hydrol. Earth Syst. Sci., 15, 2007-2024, doi:10.5194/hess-15-2007-2011, 2011.

Hughes, D. A.: Modelling semi-arid and arid hydrology and water resources - the southern African experience, in: Hydrological Modelling in Arid and Semi-Arid Areas, Cambridge University Press, Cambridge, 2007.

Hughes, D. A.: Unsaturated zone fracture flow contributions to stream flow: evidence for the process in South Africa and its importance, Hydrol. Process., 24, 767-774, doi:10.1002/hyp.7521, 2010.

Hughes, J. D., Khan, S., Crosbie, R. S., Helliwell, S., and Michalk, D. L.: Runoff and solute mobilization processes in a semiarid headwater catchment, Water Resour. Res., 43, W09402, doi:10.1029/2006wr005465, 2007. 
Kennedy, C. D., Bataille, C., Liu, Z. F., Ale, S., VanDeVelde, J., Roswell, C. R., Bowling, L. C., and Bowen, G. J.: Dynamics of nitrate and chloride during storm events in agricultural catchments with different subsurface drainage intensity (Indiana, USA), J. Hydrol., 466-467, 1-10, doi:10.1016/j.jhydrol.2012.05.002, 2012.

Klaus, J. and McDonnell, J. J.: Hydrograph separation using stable isotopes: review and evaluation, J. Hydrol., 505, 47-64, doi:10.1016/j.jhydrol.2013.09.006, 2013.

Laudon, H. and Slaymaker, O.: Hydrograph separation using stable isotopes, silica and electrical conductivity: an alpine example, J. Hydrol., 201, 82-101, doi:10.1016/S0022-1694(97)00030-9, 1997.

Liu, F. J., Williams, M. W., and Caine, N.: Source waters and flow paths in an alpine catchment, Colorado Front Range, United States, Water Resour. Res., 40, W09401, doi:10.1029/2004wr003076, 2004.

Love, D., Uhlenbrook, S., Corzo-Perez, G., Twomlow, S., van der Zaag, P.: Rainfall-interception-evaporation-runoff relationships in a semi-arid catchment, northern Limpopo basin, Zimbabwe, Hydrolog. Sci. J., 55, 687-703, 2010.

Mallory, S. and Beater, A.: Inkomati Water Availability Assessment Study (IWAAS), Department of Water Affairs and Forestry (DWAF), Pretoria, 2009.

Marc, V., Didon-Lescot, J. F., and Michael, C.: Investigation of the hydrological processes using chemical and isotopic tracers in a small Mediterranean forested catchment during autumn recharge, J. Hydrol., 247, 215-229, doi:10.1016/S0022-1694(01)00386-9, 2001.

McGlynn, B. L. and McDonnell, J. J.: Quantifying the relative contributions of riparian and hillslope zones to catchment runoff, Water Resour. Res., 39, SWC21-SWC220, 2003.

Midgley, D. C., Pittman, W. V., and Middleton, B. J.: Surface Water Resources of South Africa 1990, Water Research Commission Pretoria Report No. 298/1/94, Water Research Commission, Pretoria, 1994.

Mostert, A., McKenzie, R., and Crerar, S.: A rainfall/runoff model for ephemeral rivers in an arid or semi-arid environment, 6th South African National Hydrology Symposium, Pietermaritzburg, 219-224, 1993.

Muñoz-Villers, L. E. and McDonnell, J. J.: Runoff generation in a steep, tropical montane cloud forest catchment on permeable volcanic substrate, Water Resour. Res., 48, W09528, doi:10.1029/2011WR011316, 2012.

Munyaneza, O., Wenninger, J., and Uhlenbrook, S.: Identification of runoff generation processes using hydrometric and tracer methods in a meso-scale catchment in Rwanda, Hydrol. Earth Syst. Sci., 16, 1991-2004, doi:10.5194/hess-16-1991-2012, 2012.

Nkomo, S. and van der Zaag, P.: Equitable water allocation in a heavily committed international catchment area: the case of the Komati Catchment, Phys. Chem. Earth A/B/C, 29, 1309-1317, doi:10.1016/j.pce.2004.09.022, 2004.

Pearce, A. J., Stewart, M. K., and Sklash, M. G.: Storm Runoff Generation in Humid Headwater Catchments, 1. Where Does the Water Come From?, Water Resour. Res., 22, 1263-1272, 1986.

Petersen, R.: A conceptual understanding of groundwater recharge processes and surface-groundwater interactions in the Kruger National Park Master in the Faculty of Natural Sciences, Depart- ment of Earth Sciences, University of the Western Cape, Bellville, 2012.

R Development Core Team: R: A Language and Environment for Statistical Computing: http://www.R-project.org, last access: 1 August 2014.

Sengo, D. J., Kachapila, A., van der Zaag, P., Mul, M., and Nkomo, S.: Valuing environmental water pulses into the Incomati estuary: Key to achieving equitable and sustainable utilisation of transboundary waters, Phys. Chem. Earth A/B/C, 30, 648-657, doi:10.1016/j.pce.2005.08.004, 2005.

Schulze, R. E.: South African atlas of agrohydrology and climatology, Water Research Commission, Pretoria, 1997.

Sharpe, M. R., Sohnge, A. P., Zyl, J. S. V., Joubert, D. K., Mulder, M. P., ClubleyArmstrong, A. R., Plessis, C. P. D., Eeden, O. R. V., Rossouw, P. J., Visser, D. J. L., Viljoen, M. J., and Taljaard, J. J.: 2530 Barberton, Department of Minerals and Energy Affairs, Government Printer, South Africa, 1986.

Slinger, J. H., Hilders, M., and Dinis, J.: The practice of transboundary decision making on the Incomati River, Ecol. Soc., 15, 1, 2010.

Smith, R. E. and Goodrich, D. C.: Rainfall Excess Overland Flow, in: Encyclopedia of Hydrological Sciences, edited by: Anderson, M. G., John Wiley \& Sons, Ltd, doi:10.1002/0470848944.hsa117, 2006.

Smithers, J., Schulze, R., Pike, A., and Jewitt, G.: A hydrological perspective of the February 2000 floods: A case study in the Sabie River Catchment, Water South Africa, Water SA, 325-332, doi:10.4314/wsa.v27i3.4975, 2001.

SASRI - South African Sugarcane Research Institute: http://portal.sasa.org.za/weatherweb/weatherweb.ww_menus. menuframe?menuid=1, last access: 1 October 2013.

Tetzlaff, D. and Soulsby, C.: Sources of baseflow in larger catchments - Using tracers to develop a holistic understanding of runoff generation, J. Hydrol., 359, 287-302, doi:10.1016/j.jhydrol.2008.07.008, 2008.

Trambauer, P., Maskey, S., Winsemius, H., Werner, M., and Uhlenbrook, S.: A review of continental scale hydrological models and their suitability for drought forecasting in (sub-Saharan) Africa, Phys. Chem. Earth, 66, 16-26, 2013.

Uhlenbrook, S., and Hoeg, S.: Quantifying uncertainties in tracerbased hydrograph separations: a case study for two-, three- and five-component hydrograph separations in a mountainous catchment, Hydrol. Process., 17, 431-453, doi:10.1002/Hyp.1134, 2003.

Uhlenbrook, S. and Leibundgut, C.: Development and validation of a process oriented catchment model based on dominating runoff generation processes, Phys.Chem. Earth B, 25, 653-657, doi:10.1016/S1464-1909(00)00080-0, 2000.

Uhlenbrook, S., Frey, M., Leibundgut, C., and Maloszewski, P.: Hydrograph separations in a mesoscale mountainous basin at event and seasonal timescales, Water Resour. Res., 38, 311-314, doi:10.1029/2001WR000938, 2002.

UNEP: World atlas of desertification 2ED, United Nations Environment Programme (UNEP), London, UK, 1997.

Van der Zaag, P. and Carmo Vaz, A.: Sharing the Incomati water:cooperation and competition in the balance, Water Policy, 5, 346-368, 2003.

Van Wyk, E., van Tonder, G. J., and Vermeulen, D.: Characteristics of local groundwater recharge cycles in South African semi-arid 
hard rock terrains: Rainfall-groundwater interaction, Water SA, 38, 747-754, 2012.

Wang, R., Kumar, M., and Marks, D.: Anomalous trend in soil evaporation in a semi-arid, snow-dominated watershed, Adv. Water Resour., 57, 32-40, 2013.

Weiler, M., McGlynn, B. L., McGuire, K. J., and McDonnell, J. J.: How does rainfall become runoff? A combined tracer and runoff transfer function approach, Water Resour. Res., 39, 1315, doi:10.1029/2003WR002331, 2003.

Wenninger, J., Uhlenbrook, S., Lorentz, S., and Leibundgut, C.: Idenfication of runoff generation processes using combined hydrometric, tracer and geophysical methods in a headwater catchment in South Africa, Hydrolog. Sci. J., 53, 65-80, doi:10.1623/hysj.53.1.65, 2008.
Wheater, H., Sorooshian, S., and Sharma, K. D.: Hydrological modelling in arid and semi-arid areas, University Press, Cambridge, UK, 195 pp., 2008.

Winston, W. E. and Criss, R. E.: Geochemical variations during flash flooding, Meramec River basin, May 2000, J. Hydrol., 265, 149-163, doi:10.1016/S0022-1694(02)00105-1, 2002.

WRC: Water resources of South Africa, 2005 study (WR2005), PretoriaTT381, Pretoria, 2005. 